\title{
Origin of Bentonites and Detrital Zircons of the Paleocene Basilika Formation, Svalbard
}

\section{OPEN ACCESS}

Edited by:

Craig Lundstrom

University of Illinois, USA

Reviewed by:

Lotte Melchior Larsen,

Geological Survey of Denmark and

Greenland, Denmark

Fernando Corfu,

University of Oslo, Norway

${ }^{*}$ Correspondence:

Felix J. Elling

felling@uni-bremen.de

Cornelia Spiegel

cornelia.spiege/@uni-bremen.de

${ }^{\dagger}$ Present Address:

Felix J. Elling,

Department of Earth and Planetary

Sciences, Harvard University,

Cambridge, MA, USA;

Niklas Allroggen

Institute of Earth and Environmental

Science, University of Potsdam,

Potsdam, Germany

Specialty section:

This article was submitted to Geochemistry,

a section of the journal

Frontiers in Earth Science

Received: 30 March 2016

Accepted: 22 June 2016

Published: 07 July 2016

Citation:

Elling FJ, Spiegel C, Estrada S,

Davis DW, Reinhardt L,

Henjes-Kunst $F$, Allroggen $N$,

Dohrmann R, Piepjohn K and Lisker F

(2016) Origin of Bentonites and

Detrital Zircons of the Paleocene

Basilika Formation, Svalbard.

Front. Earth Sci. 4:73

doi: 10.3389/feart.2016.00073

\begin{abstract}
Felix J. Elling ${ }^{1,2 * \dagger}$, Cornelia Spiegel ${ }^{1 *}$, Solveig Estrada ${ }^{3}$, Donald W. Davis ${ }^{4}$, Lutz Reinhardt ${ }^{3}$, Friedhelm Henjes-Kunst ${ }^{3}$, Niklas Allroggen ${ }^{1 \dagger}$, Reiner Dohrmann ${ }^{3}$, Karsten Piepjohn ${ }^{3}$ and Frank Lisker ${ }^{1}$
\end{abstract}

${ }^{1}$ Department of Geosciences, University of Bremen, Bremen, Germany, ${ }^{2}$ MARUM - Center for Marine Environmental Sciences, University of Bremen, Bremen, Germany, ${ }^{3}$ Federal Institute for Geosciences and Natural Resources (BGR), Hannover, Germany, ${ }^{4}$ Department of Geology, University of Toronto, Toronto, ON, Canada

The Paleocene was a time of transition for the Arctic, with magmatic activity of the High Arctic Large Igneous Province (HALIP) giving way to magmatism of the North Atlantic Large Igneous Province in connection to plate tectonic changes in the Arctic and North Atlantic. In this study we investigate the Paleocene magmatic record and sediment pathways of the Basilika Formation exposed in the Central Tertiary Basin of Svalbard. By means of geochemistry, Sm-Nd isotopic signatures, and zircon U-Pb geochronology we investigate the characteristics of several bentonite layers contained in the Basilika Formation, as well as the provenance of the intercalated clastic sediments. Our data show that the volcanic ash layers of the Basilika Formation, which were diagenetically altered to bentonites, originate from alkaline continental-rift magmatism such as the last, explosive stages of the HALIP in North Greenland and the Canadian Arctic. The volcanic ash layers were deposited on Svalbard in a flat shelf environment with dominant sediment supply from the east. Dating of detrital zircons suggests that the detritus was derived from Siberian sources, primarily from the Verkhoyansk Fold-and-Thrust Belt, which would require transport over $\sim 3000 \mathrm{~km}$ across the Arctic.

\footnotetext{
Keywords: Paleogene, Svalbard, Central Tertiary Basin, Basilika formation, bentonite, zircon provenance, High Arctic Large Igneous Province, North Atlantic Large Igneous Province
}

\section{INTRODUCTION}

The Paleogene was a time of profound change in the Arctic realm (Figure 1): caused by the contemporaneous spreading in the Baffin Bay/Labrador Sea and the North Atlantic, Greenland moved north and collided with Svalbard in the East and with Ellesmere Island (Canadian High Arctic) in the West (e.g., Talwani and Eldholm, 1977; Roest and Srivastava, 1989; Tessensohn and Piepjohn, 2000; Oakey and Chalmers, 2012). This led to the so-called Eurekan deformation that affected North Greenland, Ellesmere Island and Svalbard, and caused the formation of the West Spitsbergen Fold-and-Thrust Belt on Svalbard (e.g., Tessensohn and Piepjohn, 2000). Detailed timing of Eurekan deformation is still poorly constrained, but presumably commenced in the Paleocene, culminated in the Eocene, and may have lasted into the Oligocene (Tessensohn and Piepjohn, 2000; Piepjohn et al., 2013). Concurrent with Eurekan compression, extension prevailed further north, leading to the onset of spreading along the Gakkel Ridge, separation of the 


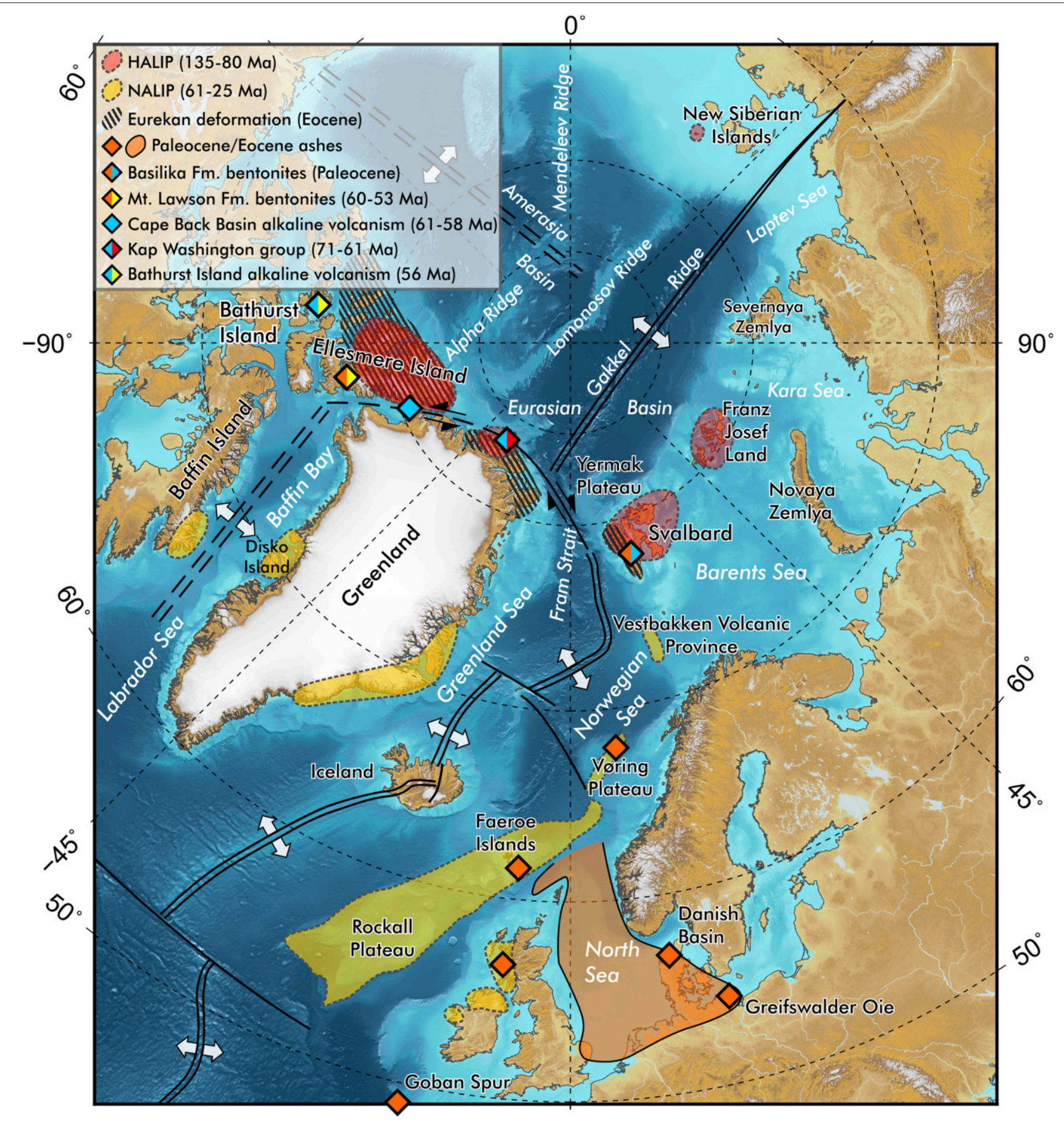

FIGURE 1 | Overview over the tectono-magmatic framework of the Arctic and North Atlantic oceans indicating two major magmatic phases expressed in the late Cretaceous high arctic large igneous province (HALIP) and the Paleocene-Eocene North Atlantic volcanic province (NALIP) as well as the widespread occurrence of Paleocene to Eocene ash deposits (compiled from Knox and Morton, 1988; Hopper et al., 2003; Larsen et al., 2003a; Storey et al., 2007; Estrada et al., 2010; Tegner et al., 2011; Reinhardt et al., 2013, and references therein).

Lomonosov Ridge from the Barents Sea Shelf and the opening of the Eurasia Basin (e.g., Pitman and Talwani, 1972; Srivastava, 1985; Jackson and Gunnarsson, 1990; Tessensohn and Piepjohn, 2000; Døssing et al., 2013b). While the convergent movements were seemingly not associated with magmatic activity (cf.
Tessensohn and Piepjohn, 2000), extensional tectonics were accompanied by magmatism with continental rift signature from the Early Cretaceous onwards until $\sim 61$ Ma (e.g., Tarduno, 1998; Estrada et al., 2001; Maher, 2001; Tegner et al., 2011; Thorarinsson et al., 2011b). During the Paleogene, magmatism 
in the Arctic was predominantly intrusive and basaltic effusive (e.g., Storey et al., 1998; Tegner et al., 1998; Storey et al., 2007; Thorarinsson et al., 2011b), but explosive volcanic activity also occurred, as evidenced by volcanic ash layers on Ellesmere Island and Svalbard (e.g., Dypvik and Nagy, 1978; Reinhardt et al., 2013). These ash layers are preserved in Paleogene sediments, i.e., in the Eureka Sound Group on Ellesmere Island and in the Central Tertiary Basin on Svalbard (Dypvik and Nagy, 1978; Reinhardt et al., 2013). Both depocenters are dominated by clastic deposition, and their stratigraphy and provenance are still poorly resolved (e.g., Miall, 1991; Dallmann, 1999). For the Central Tertiary Basin, a sediment source from the rising West Spitsbergen Fold-and-Thrust Belt to the west is assumed from $\sim$ mid-Eocene onwards (e.g., Helland-Hansen, 1990). Before that time, during the Paleocene and early Eocene, the basin received detritus from easterly directions, where a not further specified highland must have undergone active erosion (e.g., HellandHansen, 1990; Bruhn and Steel, 2003).

This study focuses on the Paleocene Basilika Formation of the Central Tertiary Basin on Svalbard. This formation comprises deltaic to deep-water clastic sediments (e.g., Steel et al., 1981), supposedly sourced from the east (Steel et al., 1981; Helland-Hansen, 1990; Müller and Spielhagen, 1990), and contains several altered volcanic ash layers that were previously characterized as bentonites (e.g., Gripp, 1927; Nagy, 1966; Dypvik and Nagy, 1978). The primary aim of this study is to geochemically characterize the Basilika bentonites in order to derive information on the origin of their volcanic sources and their plate tectonic environment. Furthermore, the ash layers will be compared to the Paleocene bentonites occurring on Ellesmere Island, to test whether both volcanic deposits may have derived from the same source (taking into account that Ellesmere Island and Svalbard were situated relatively close to each other during the Paleocene). For this, we performed main and trace element geochemical as well as $\mathrm{Sm}$-Nd isotope analyses on the Basilika Formation bentonites as well as on the Ellesmere Island bentonites (complementing the data published by Reinhardt et al., 2013). No primary magmatic zircons were found in the bentonites, but we used $\mathrm{U}-\mathrm{Pb}$ dating of detrital zircons contained in the bentonites to characterize the provenance of the Basilika Formation and to constrain the paleogeographic setting and sediment transport pathways during the Paleocene.

\section{GEOLOGICAL SETTING}

\section{Cretaceous-Paleogene Geology of Svalbard and Regional Tectono-Magmatic Framework}

The Svalbard archipelago represents the uplifted north-western margin of the Barents shelf and is confined to the north by the Eurasia Basin of the Arctic Ocean and to the west by the Fram Strait (Figure 1). Svalbard has a complex tectono-magmatic history comprising multiple orogenies and magmatic events, which is to a great extent shared with that of the circumarctic land masses, most prominently by Ellesmere Island and Greenland, but also with Baltica.
During the Cretaceous the northernmost regions of Ellesmere Island, Greenland and Svalbard were adjacent to each other at a paleolatitude of about $80^{\circ} \mathrm{N}$ (Lawver et al., 1990; Faleide et al., 1993; Harland, 1997). During the Early Cretaceous, fineclastic sediments were deposited on Svalbard, followed by delta progradation from the northwest to the southeast with sediment transport possibly from Greenland (Røhr, 2009). Exhumation and erosion of northern Svalbard caused by the opening of the Amerasia Basin during the Cretaceous may have provided another source of detritus feeding the prograding delta system (Dörr et al., 2013). The Early Cretaceous sediments of Svalbard are truncated by an erosional unconformity and hence Late Cretaceous strata are completely missing (Dallmann, 1999).

Intrusive and extrusive magmatism on Svalbard in the Early Cretaceous was coeval with widespread volcanism throughout the Arctic and connected to the formation of the Cretaceous (to Paleogene) High Arctic Large Igneous Province (HALIP) (Tarduno, 1998; Maher, 2001). The HALIP is manifested in Cretaceous flood basalts, dykes and sills on eastern Svalbard and the adjacent subseafloor (Maher, 2001; Minakov et al., 2012; Corfu et al., 2013), Franz Josef Land, Ellesmere Island, and other islands in the Canadian Arctic (Embry and Osadetz, 1988; Estrada and Henjes-Kunst, 2004, 2013; Corfu et al., 2013; Jowitt et al., 2014), as well as Late Cretaceous to Paleocene dykes and extrusive magmatism on northern Greenland and the Canadian Arctic islands (Figure 1; e.g., Estrada et al., 2001; Kontak et al., 2001; Tegner et al., 2011; Thorarinsson et al., 2011a).

The HALIP comprises a tholeiitic suite (ca. 130-90 Ma) and an alkaline suite (ca. 90-60 Ma; Estrada and Henjes-Kunst, 2004; Buchan and Ernst, 2006; Tegner et al., 2011; Thorarinsson et al., 2011b; Estrada, 2015). The tholeiitic suite is associated with extensional tectonics in the High Arctic related to the breakup of the Arctic continental land masses and the subsequent opening of the Amerasia Basin (Tegner et al., 2011; Døssing et al., 2013b). The extrusion of the alkaline suite of the HALIP is typical for continental rifts and does only partly overlap geographically with the tholeiitic suite (Tegner et al., 2011). Alkaline mafic to felsic volcanism is known from northwest Ellesmere Island (Hansen Point Volcanic Complex at around $80 \mathrm{Ma}$; Embry and Osadetz, 1988; Estrada and Henjes-Kunst, 2004, 2013), the Kap Washington Group in North Greenland (71-61 Ma; Tegner et al., 2011; Thorarinsson et al., 2011a,b), from the Cape Back Basin on Ellesmere Island, evidenced by deposition of volcanogenic detritus (61-58 Ma; Estrada et al., 2010) and from Freeman Cove, Bathurst Island (56 Ma; Day et al., 2005; Figure 1).

In the High Arctic volcanism ceased during the Paleogene probably due to compressional tectonics induced by the northwards movement of Greenland (Tegner et al., 2011). Coevally with the termination of volcanism in the High Arctic, a Large Igneous Province formed in the North Atlantic region (NALIP). The NALIP is expressed in flood basalts on eastern Greenlandas well as flood basalts and alkaline tuffs in western central Greenland (Storey et al., 1998, 2007; Tegner et al., 1998; Larsen and Pedersen, 2009; Larsen et al., 2016). Moreover, Paleocene bentonites were observed on Svalbard as well as Ellesmere Island and are particularly widespread in the North 
Atlantic region (Figure 1; Major and Nagy, 1972; Dypvik and Nagy, 1978; Larsen et al., 2003a; Grist and Zentilli, 2004; Reinhardt et al., 2013).

Until $\sim 55 \mathrm{Ma}$, Greenland was part of the Eurasian plate. The plate boundaries between the Eurasian and North American plates were located in the Labrador Sea/Baffin Bay and within the Eurasia Basin. Both plate boundaries were connected by a putative sinistral transform fault, the existence and exact positioning of this fault currently being under debate (e.g., Tessensohn and Piepjohn, 2000; Oakey and Chalmers, 2012; Greiner and Neugebauer, 2013; Frisch and Dawes, 2014; Neugebauer and Greiner, 2014). From 55 Ma onwards, Greenland was separated from both Eurasia and North America by coeval seafloor spreading in the Labrador Sea/Baffin Bay and in the northern North Atlantic Ocean (Pitman and Talwani, 1972; Roest and Srivastava, 1989; Tessensohn and Piepjohn, 2000), as well as in the Eurasia Basin (Tessensohn and Piepjohn, 2000). Seafloor spreading in the Labrador Sea/Baffin Bay ceased at $\sim 33 \mathrm{Ma}$ (Kristoffersen and Talwani, 1977), while the North Atlantic spreading system continued to propagate northwards, separating Greenland/North America from Eurasia/Svalbard from the Oligocene onwards (e.g., Talwani and Eldholm, 1977; Gaina et al., 2009, 2015; Seton et al., 2012; Døssing et al., 2013a, 2016).

The northwards movement of Greenland as an independent micro-plate between 56 and $33 \mathrm{Ma}$ led to intracontinental compression along the margins of Eurasia and North America, which is expressed in the Eurekan deformation of Svalbard, northeast Greenland, and Ellesmere Island (Tessensohn and Piepjohn, 2000; CASE Team, 2001). These deformations were initiated during the Early Paleocene and culminated during the Eocene (Oakey and Chalmers, 2012; e.g., Piepjohn et al., 2013), forming the West Spitsbergen Fold-and-Thrust Belt (Bergh et al., 1997; Piepjohn et al., 2001; von Gosen and Piepjohn, 2001). The NNW-SSE striking Central Tertiary Basin (CTB, Figure 2) was formed as a foreland basin of the fold-and-thrust belt and filled with the eroded material of the bulge. Compression in the West Spitsbergen Fold-and-Thrust Belt ceased during the Late Eocene followed by a short extensional episode during the early Oligocene (Braathen et al., 1999; CASE Team, 2001).

\section{Stratigraphy of the Central Tertiary Basin (CTB)}

The main occurrence of Paleogene strata on Svalbard is in the CTB of Spitsbergen (Figure 2), the main island of the Svalbard archipelago (reviewed in Dallmann, 1999). The CTB comprises a Paleocene to Eocene clastic sedimentary sequence, the Van Mijenfjorden Group, with a preserved thickness of more than $1900 \mathrm{~m}$, which lies unconformably upon Lower Cretaceous sandstones of the Carolinefjellet Formation (Figures 3A, 4; Major and Nagy, 1964; Livšic, 1967; Harland, 1969; Major and Nagy, 1972; Livšic, 1974; Dallmann, 1999).

The base of the Van Mijenfjorden Group is formed by the Paleocene Firkanten and Basilika formations. These represent an overall transgressive succession, evolving from continental to marginal marine sandstones of the Firkanten Formation to the marine shales of the Basilika Formation (Steel et al., 1981; Figure 4). The Basilika Formation consists of black mudstones, shales and siltstones with intercalated bentonite horizons that were deposited in a prodelta environment (Steel et al., 1985; Müller and Spielhagen, 1990). The lower part of the formation features a fining upwards sequence, which reverses into coarsening upwards in the upper part of the formation (Dallmann, 1999). This upper part of the formation marks the onset of a regression, leading to a gradual transition from marine shales into the marine glauconitic, highly bioturbated sandstones of the Grumantbyen Formation (Steel et al., 1981). The overlying strata comprise a transgression-regression cycle recorded in the Paleocene-Eocene Frysjaodden Formation and the Eocene Battfjellet and Aspelintoppen formations (Charles et al., 2011; Figure 4). Sedimentation in the CTB ceased during the Middle Oligocene (Harland, 1997). The thickness of the Paleogene formations varies greatly throughout the CTB. The Basilika Formation thins out from more than $350 \mathrm{~m}$ in the southwest to $\sim 10 \mathrm{~m}$ in the northeast (Dallmann, 1999).

Bentonites are very common in the Basilika Formation. They were first described by Gripp (1927) as thin, laterally consistent beds of plastic clay and have been observed in several locations within the CTB (Nagy, 1966; Vonderbank, 1970; Major and Nagy, 1972; Dypvik and Nagy, 1978; Major et al., 2001). Dypvik and Nagy (1978) described the bentonites as very fine-grained but poorly sorted, with maximum grain sizes between 15 and $40 \mu \mathrm{m}$ and consisting of $\sim 80 \%$ clay minerals - mostly illite/smectitewith minor fractions of quartz and feldspar, indicative of altered, aeolian-transported volcanic material. Based on the grain size they concluded that the source area was located at a distance of $100-200 \mathrm{~km}$ from the area of deposition but more distant sources were not excluded. Except for the bentonites of the Basilika Formation, only few indications of Paleogene volcanism have been found on Svalbard. Major and Nagy (1972) reported that bentonites of $10-20 \mathrm{~cm}$ thickness had been observed adjacent to the coal seams of the Firkanten Formation. Further bentonite layers of Paleocene age are known from numerous coal exploration wells (Jones et al., 2015). Additionally, bentonites were observed in the Frysjaodden Formation, situated in the interval of the carbon isotope excursion of the PaleoceneEocene Thermal Maximum, and thus provide constraints on the numerical age of the Paleocene-Eocene boundary on Spitsbergen (Charles et al., 2011).

The biostratigraphy of the Van Mijenfjorden Group is poorly resolved (reviewed in Manum and Throndsen, 1986; Čepek and Krutzsch, 2001). While earlier publications proposed just a Paleocene age for the Firkanten Formation (Manum, 1962), more recent studies place it in the Selandian to Thanetian (Middle to Upper Paleocene) based on the occurrence of a coccolithophore species (Čepek, 2001; Čepek and Krutzsch, 2001). Normapolles flora found in the Basilika Formation was assigned to a wide age range from uppermost Cretaceous to middle Paleocene (Čepek and Krutzsch, 2001). Manum and Throndsen (1986) suggested that the Basilika Formation was deposited in the Lower to Upper Paleocene transition based on 


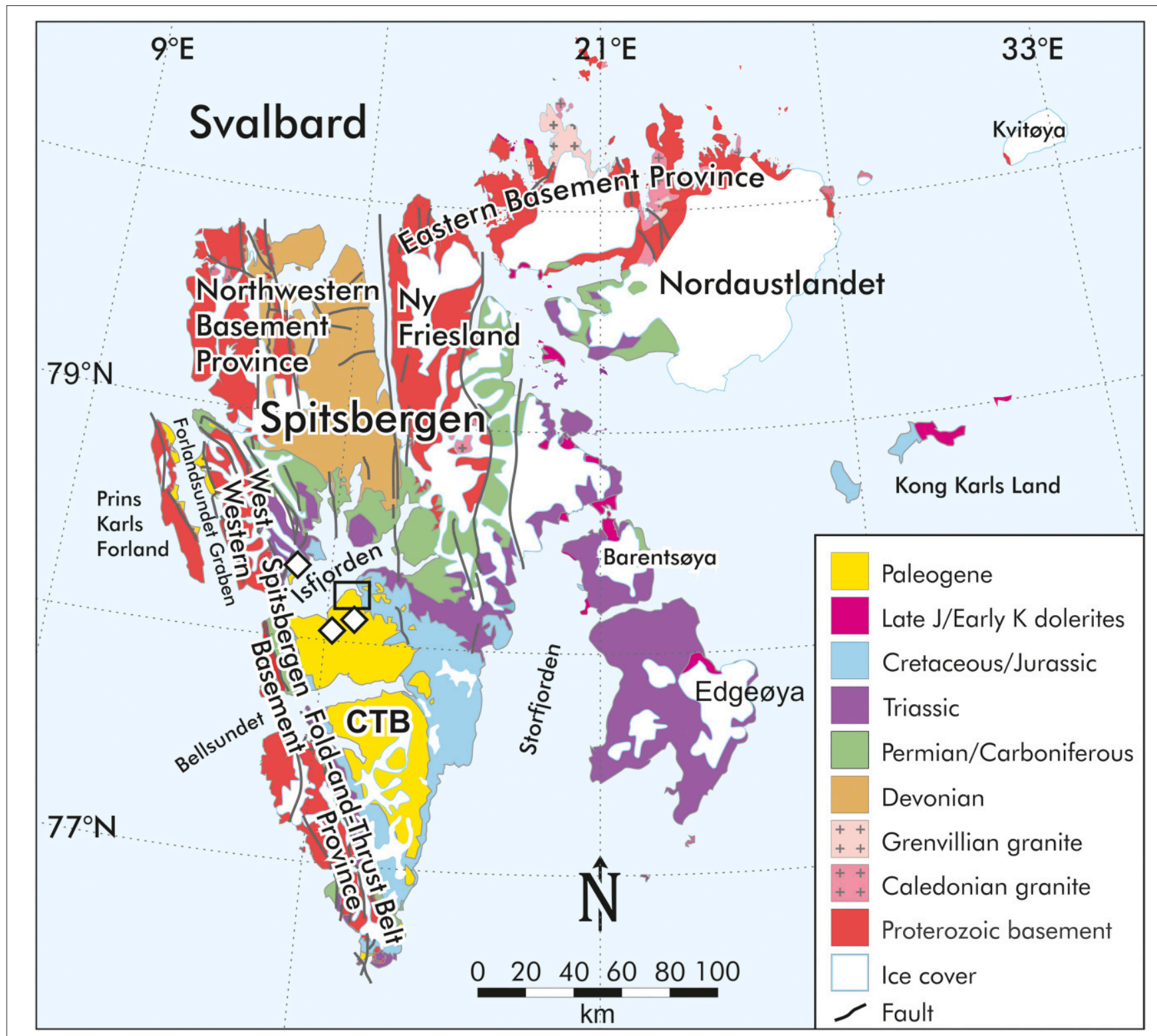

FIGURE 2 | Geological map of Svalbard showing the location of the working area in 2010 (open rectangle; Figure 3) within the Central Tertiary Basin of Spitsbergen (CTB; based on Dallmann, 1999). Diamonds indicate sampling sites during the CASE 1 expedition in 1992.

dynocysts. However, a Danian (Early Paleocene) age for the lower part of the Basilika Formation is not very likely due to the Middle to Upper Paleocene deposition age of the underlying Firkanten Formation (Čepek, 2001; Čepek and Krutzsch, 2001). The Late Paleocene age of the overlying Grumantbyen Formation is again poorly constrained. The Grumantbyen Formation is overlain by the Frysjaodden Formation, which contains a bentonite layer dated as $55.9 \pm 0.1 \mathrm{Ma}$ (Paleocene/Eocene boundary after Gradstein et al., 2012) by U-Pb geochronology (Charles et al., 2011). Summarizing the biostratigraphic and radiometric age constraints as well as the lithostratigraphic correlations for the CTB formations and considering recent changes in the Geologic Time Scale, a latest Danian to early Thanetian time interval (ca.
62-58 Ma) for the deposition of the Basilika Formation can be estimated.

\section{SAMPLING AND FIELD OBSERVATIONS}

The Bjørndalen section of the Basilika Formation consists of two outcrops along the river Bjørndalselva and contains a total of four bentonite layers (Table 1, Figures 3, 5). The sandstone cliffs of the Firkanten Formation are well above the river at the seaward valley entrance (Figure 3A). Further up the valley, the river cuts first into the Firkanten Formation and subsequently into the Basilika and Grumantbyen Formations, forming 


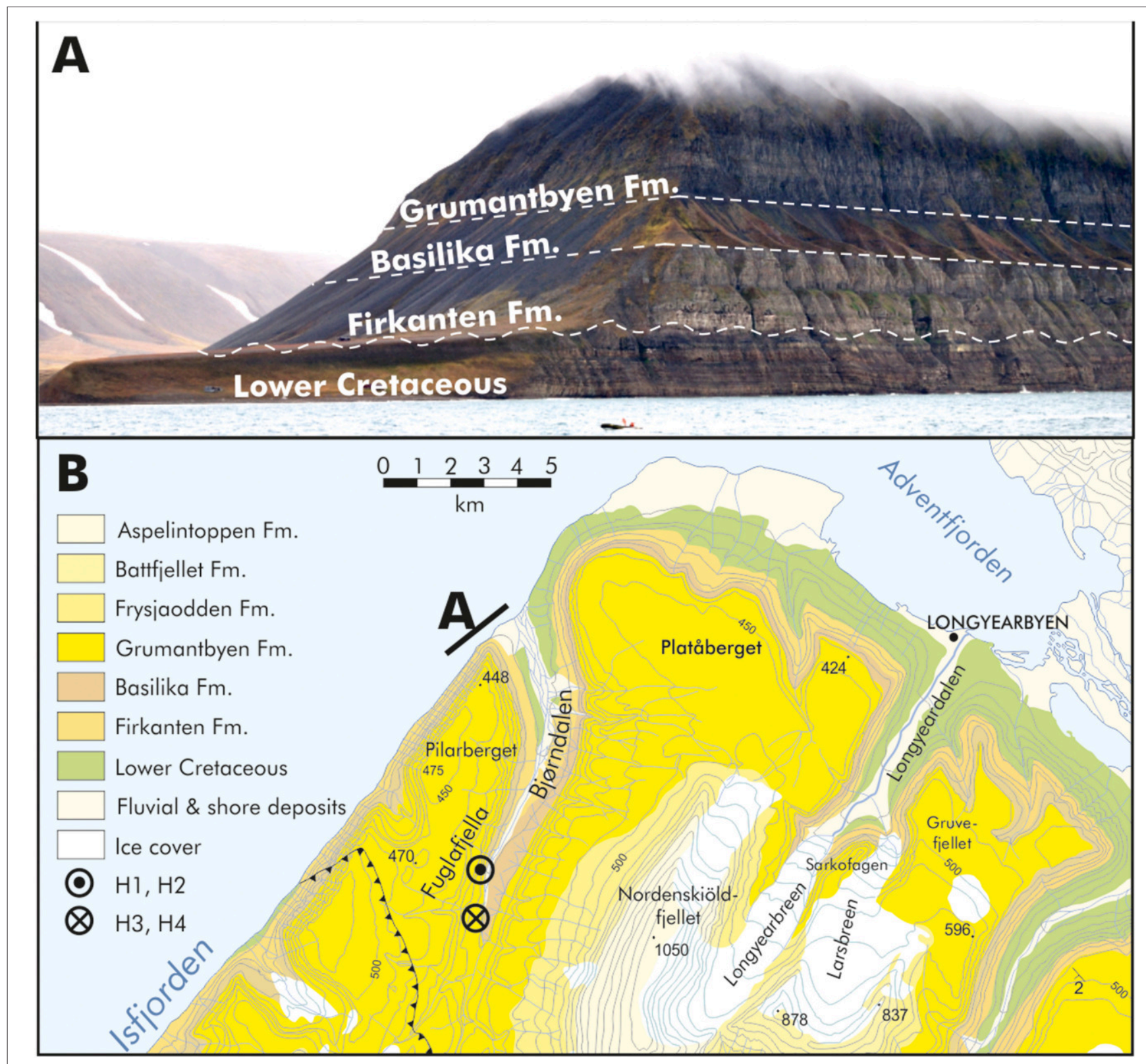

FIGURE 3 | (A) Stratigraphic position of the Basilika Formation within the Van Mijenfjorden Group in the Bjørndalen area (viewed from NW). (B) Geologic map of Bjørndalen (based on Major et al., 2001) showing sampling locations.

well exposed outcrops. The exposures of the Firkanten and Basilika Formations along the river were logged stratigraphically (Figure 5).

The lower, middle, and uppermost parts of the Firkanten Formation are scree-covered, so that just a section of $11.5 \mathrm{~m}$ of the upper part could be investigated. The formation comprises mostly fine-grained sandstones with intercalated siltstones and silty shales with an overall fining upwards trend. Mudclasts, clay-ironstone nodules as well as coal or plant fragments are frequent in the upper part. Bioturbation is common throughout the investigated section. The Basilika Formation is $73.5 \mathrm{~m}$ thick, dips $5^{\circ} \mathrm{SE}$ and is partly debris-covered. Therefore, the boundary to the underlying Firkanten Formation could not be observed and the outcrop of the Basilika Formation is split into several parts. The Basilika Formation consists of dark gray to black, silty shales, and siltstones with few intercalated sandstone horizons. Bioturbation is common in the lower part of the formation but absent in the middle and upper part. The formation comprises several coarsening upwards sequences from shale to siltstone. Dropstones, mostly in the range of $1-5 \mathrm{~cm}$ in diameter but rarely up to $20 \mathrm{~cm}$ can be observed throughout the formation. These consisted in all cases either of chert or quartz/quartzite. The boundary between the Basilika Formation and the overlying Grumantbyen Formation is well exposed and 


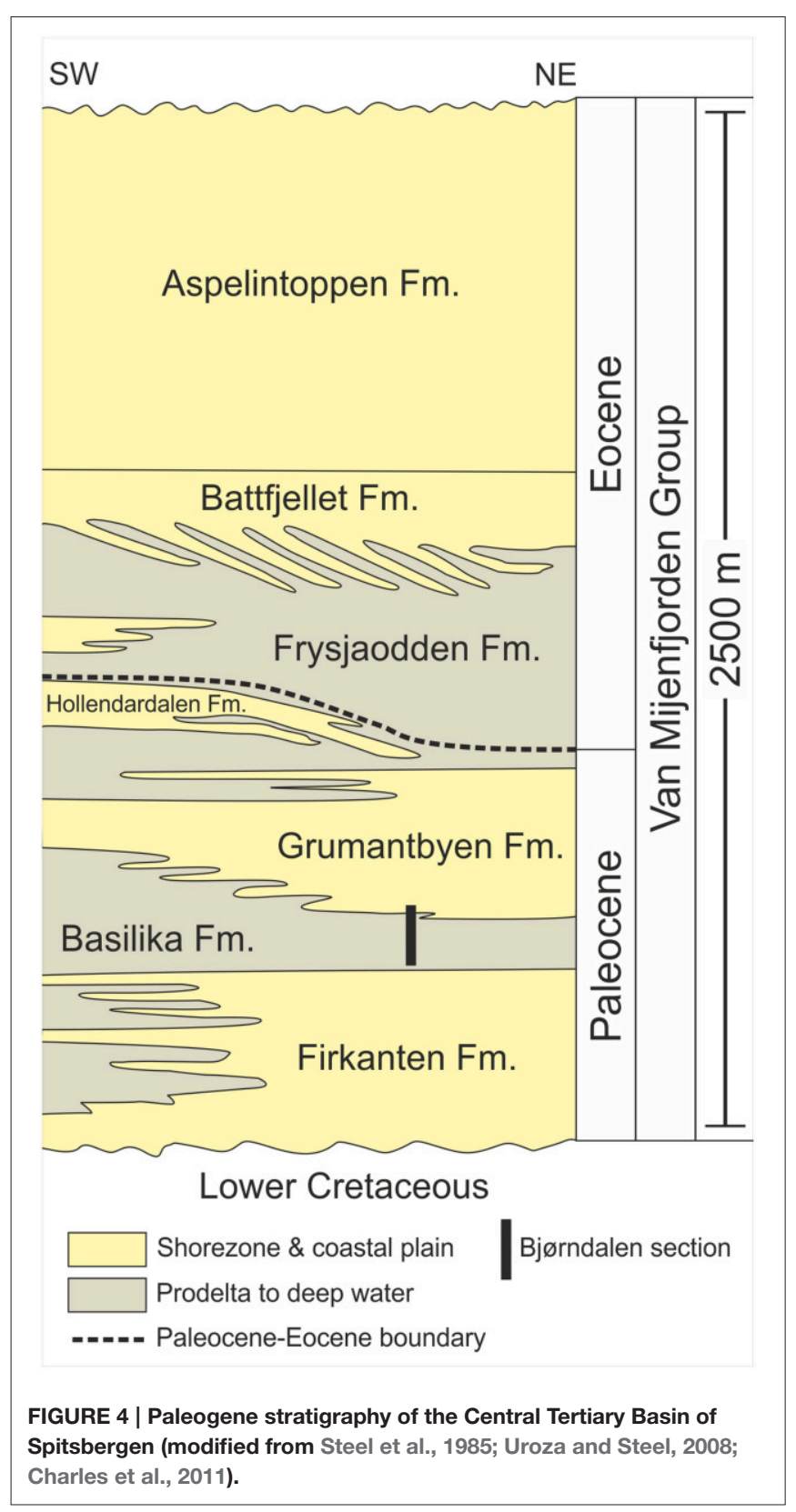

marked by the occurrence of a fine-grained glauconitic sandstone bed.

Two pairs of laterally continuous horizons of plastic, gray-weathered brownish clay were observed in the Basilika Formation and interpreted as bentonites. Horizons $\mathrm{H} 1$ and $\mathrm{H} 2$ are located in the lower part of the formation about $50 \mathrm{~cm}$ apart and are 5 and $3 \mathrm{~cm}$ thick, respectively. Horizons $\mathrm{H} 3$ and $\mathrm{H} 4$ are located in the middle part of the formation and are $2 \mathrm{~m}$ apart, with thicknesses of 3 and $5 \mathrm{~cm}$, respectively. Horizon $\mathrm{H} 3$ was subdivided into a main horizon and sub-horizon $\mathrm{H} 3 \mathrm{~b}$. The latter does not form a coherent layer but occurs sporadically several $\mathrm{cm}$ above the $\mathrm{H} 3$ main horizon.

The bentonite layers comprise plastic, gray-weathered brownish clay intercalated into shales of the lower Basilika
Formation (Horizons $\mathrm{H} 1$ and $\mathrm{H} 2$ ) and siltstones of the upper Basilika Formation (H3 and H4; Table 1, Figure 5). The horizons were laterally traceable as continuous lines of vegetation on the scree cover. Two to three samples were taken from each horizon (about $1.5 \mathrm{~kg}$ per horizon) in 2010 for petrographic, geochemical, and geochronological analyses (see Table $\mathbf{1}$ for sample numbers).

For geochemical comparisons, additional bentonite samples from the Basilika Formation collected during the CASE 1 expedition of the German Federal Institute for Geosciences and Natural Resources (BGR) in 1992 (Tessensohn et al., 2001) and two bentonite samples from the lower Paleogene Mount Lawson Formation (Eureka Sound Group) of Ellesmere Island, Canada (Reinhardt et al., 2013) were included in this study. Whole-rock geochemical data of bentonites of the Basilika Formation sampled during the CASE 1 expedition in 1992 in the northern part of the CTB complements the dataset obtained in this study (Supplementary Material). The sampling sites of the CASE 1 bentonites are located on the Erdmannflya peninsula on the northern shore of Isfjorden, as well as in Fossildalen, Russekollen, and Battfjellet to the southwest of Longyearbyen (Table 1, Figure 2). Their stratigraphic positions relative to the bentonites recovered in Bjørndalen is unknown.

\section{ANALYTICAL METHODS \\ Compositional Analyses}

Sample preparation and compositional analyses were conducted at the Federal Institute for Geosciences and Natural Resources (BGR) in Hannover, Germany. Identification of mineral phases and geochemical analyses were initially performed on homogenized whole-rock samples. Subsequently, clay fractions $(<2 \mu \mathrm{m})$ were separated from the whole-rock samples using ultrasonication and analyzed separately in order to minimize the influence of detrital components. Identification of mineral phases in whole-rock samples and $<2 \mu \mathrm{m}$ fractions was achieved by infrared spectroscopy and X-ray diffraction (XRD; Cu radiation) measurements of air dried and ethylene glycol vapor-solvated samples. Cation-exchange capacity (CEC) was measured as a qualitative indicator for bentonite using Cu-trien (Dohrmann et al., 2012). Additionally, scanning electron microscopy was performed on samples $\mathrm{H} 2$ and $\mathrm{H} 3$ for identification of volcanic glass particles. The chemical composition of the wholerock samples and $<2 \mu \mathrm{m}$ fractions was analyzed by $\mathrm{X}$ ray fluorescence (XRF) spectrometry and inductively-coupled plasma mass spectrometry (ICP-MS). Sm-Nd isotope data were obtained on the acid-digested whole-rock samples and $<2 \mu \mathrm{m}$ fractions. U-Pb ages of density-separated, hand-picked zircons were determined using laser ablation ICP-MS (LA-ICP-MS). Concordia diagrams were plotted using the Isoplot program of Ludwig (1991). Probability density plots were created using a program written by Sircombe (2004). ${ }^{206} \mathrm{~Pb} /{ }^{238} \mathrm{U}$ ages are plotted for zircons $<1000 \mathrm{Ma}$ and ${ }^{207} \mathrm{~Pb} /{ }^{206} \mathrm{~Pb}$ ages for zircons $>1000$ Ma. A detailed description of the methods can be found in the Supplementary Material (Section Analytical Methods). Results are given in Tables 2, 3 and the Supplementary Material. All data are stored in the Pangaea database and are accessible via http:// doi.pangaea.de/10.1594/PANGAEA.860807. 
TABLE 1 | Bentonite sampling sites on Svalbard (sample labels denote replicate samples from adjacent locations of the same horizon).

\begin{tabular}{|c|c|c|c|c|c|}
\hline Name & Sample & Latitude & Longitude & Stratigraphic position & Thickness (cm) \\
\hline \multicolumn{6}{|c|}{ SVALBARD, BJøRNDALEN, BASILIKA FORMATION } \\
\hline $\mathrm{H} 1$ & $8 a, 8 b$ & $78^{\circ} 11^{\prime} 20.2^{\prime \prime} \mathrm{N}$ & $15^{\circ} 17^{\prime} 11.9^{\prime \prime} \mathrm{E}$ & Lowermost bentonite horizon & 5 \\
\hline $\mathrm{H} 2$ & $7 a, 7 b$ & $78^{\circ} 11^{\prime} 20.2^{\prime \prime} \mathrm{N}$ & $15^{\circ} 17^{\prime} 11.9^{\prime \prime} \mathrm{E}$ & $0.5 \mathrm{~m}$ above $\mathrm{H} 1$ & 3 \\
\hline H3 & $5 a, 5 b$ & $78^{\circ} 10^{\prime} 57.8^{\prime \prime} \mathrm{N}$ & $15^{\circ} 17^{\prime} 3.1^{\prime \prime} \mathrm{E}$ & $2.2 \mathrm{~m}$ below $\mathrm{H} 4$ & 3 \\
\hline $\mathrm{H} 3 \mathrm{~b}$ & $5 c$ & $78^{\circ} 11^{\prime} 20.1^{\prime \prime} \mathrm{N}$ & $15^{\circ} 17^{\prime} 11.6^{\prime \prime} \mathrm{E}$ & Sub-horizon of $\mathrm{H} 3$ & $3-4$ \\
\hline $\mathrm{H} 4$ & $6 a, 6 b$ & $78^{\circ} 11^{\prime} 20.1^{\prime \prime} \mathrm{N}$ & $15^{\circ} 17^{\prime} 11.6^{\prime \prime} \mathrm{E}$ & Uppermost bentonite horizon & 5 \\
\hline $\mathrm{H} 4$ & 10 & $78^{\circ} 10^{\prime} 45.0^{\prime \prime} \mathrm{N}$ & $15^{\circ} 17^{\prime} 4.4^{\prime \prime} \mathrm{E}$ & Normal faulted $\mathrm{H} 4$ & 5 \\
\hline \multicolumn{6}{|c|}{ SVALBARD, CASE 1 EXPEDITION, BASILIKA FORMATION } \\
\hline Erdmannflya & FTS35 & $78^{\circ} 17^{\prime} 43^{\prime \prime} \mathrm{N}$ & $14^{\circ} 11^{\prime} 46^{\prime \prime} \mathrm{E}$ & - & - \\
\hline Erdmannflya & FTS36 & $78^{\circ} 17^{\prime} 43^{\prime \prime} \mathrm{N}$ & $14^{\circ} 11^{\prime} 46^{\prime \prime} \mathrm{E}$ & $\sim 20 \mathrm{~m}$ above FTS35 & - \\
\hline Fossildalen & FTS78 & $78^{\circ} 05^{\prime} 40^{\prime \prime} \mathrm{N}$ & $14^{\circ} 51^{\prime} 15^{\prime \prime} \mathrm{E}$ & 1 horizon, 3 samples & - \\
\hline Russekollen & $\mathrm{TH} 144$ & $78^{\circ} 05^{\prime} 44^{\prime \prime} \mathrm{N}$ & $15^{\circ} 10^{\prime} 23^{\prime \prime} \mathrm{E}$ & - & - \\
\hline Battfjellet & TH145 & $78^{\circ} 01^{\prime} 34^{\prime \prime} \mathrm{N}$ & $16^{\circ} 10^{\prime} 50^{\prime \prime} \mathrm{E}$ & - & - \\
\hline
\end{tabular}

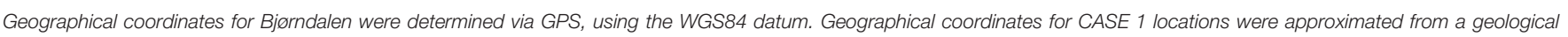
map.
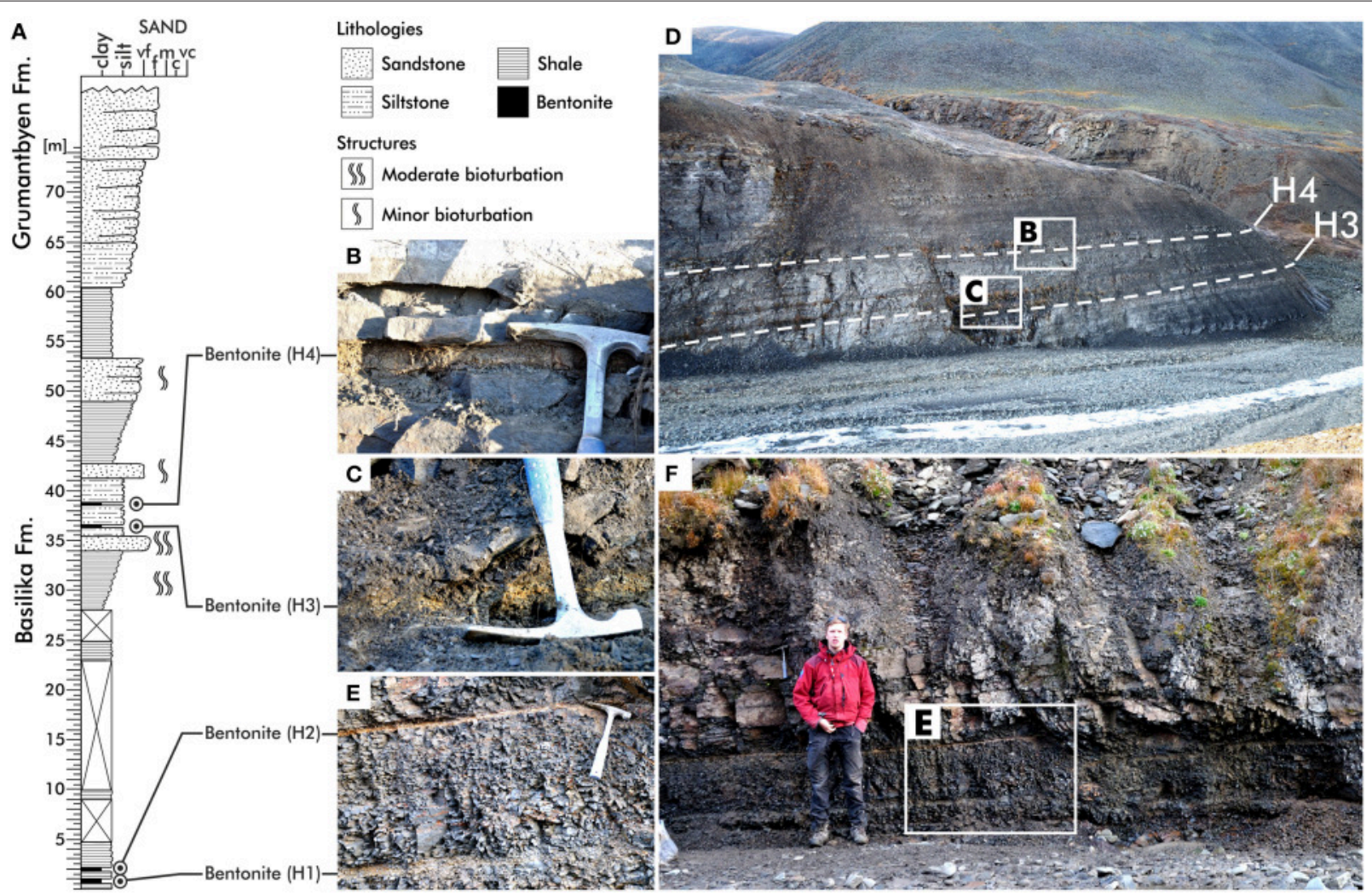

FIGURE 5 | Stratigraphic log (A) and sampled outcrops (B-F, insets are not to scale) of the Basilika Formation at Bjørndalselva, inner Bjørndalen. Bentonite thicknesses are exaggerated for visibility. Sandstone grain size indicated as vf, very fine; f, fine; m, medium; c, coarse; vc, very coarse.

\section{RESULTS AND INTERPRETATION \\ Mineralogical Composition of the Basilika Formation Bentonites}

Multiple lines of evidence indicate that the plastic clay horizons in the Basilika Formation are indeed bentonites. XRD analyses on the whole-rock powder samples revealed a composition dominated by quartz, feldspar, and smectite-rich interstratified (mixed-layered) minerals for all samples. While all samples contain traces of kaolinite and muscovite-illite, only the lower horizons $\mathrm{H} 1$ and $\mathrm{H} 2$ additionally comprise traces of anatase $\left(\mathrm{TiO}_{2}\right)$ and barite (observed during heavy mineral separation). 
TABLE 2 | Chemical composition of Basilika Formation (Bjørndalen area) and Mount Lawson Formation bentonites (<2 $\mu \mathrm{m}$ fractions) determined by X-ray fluorescence and ICP-MS.

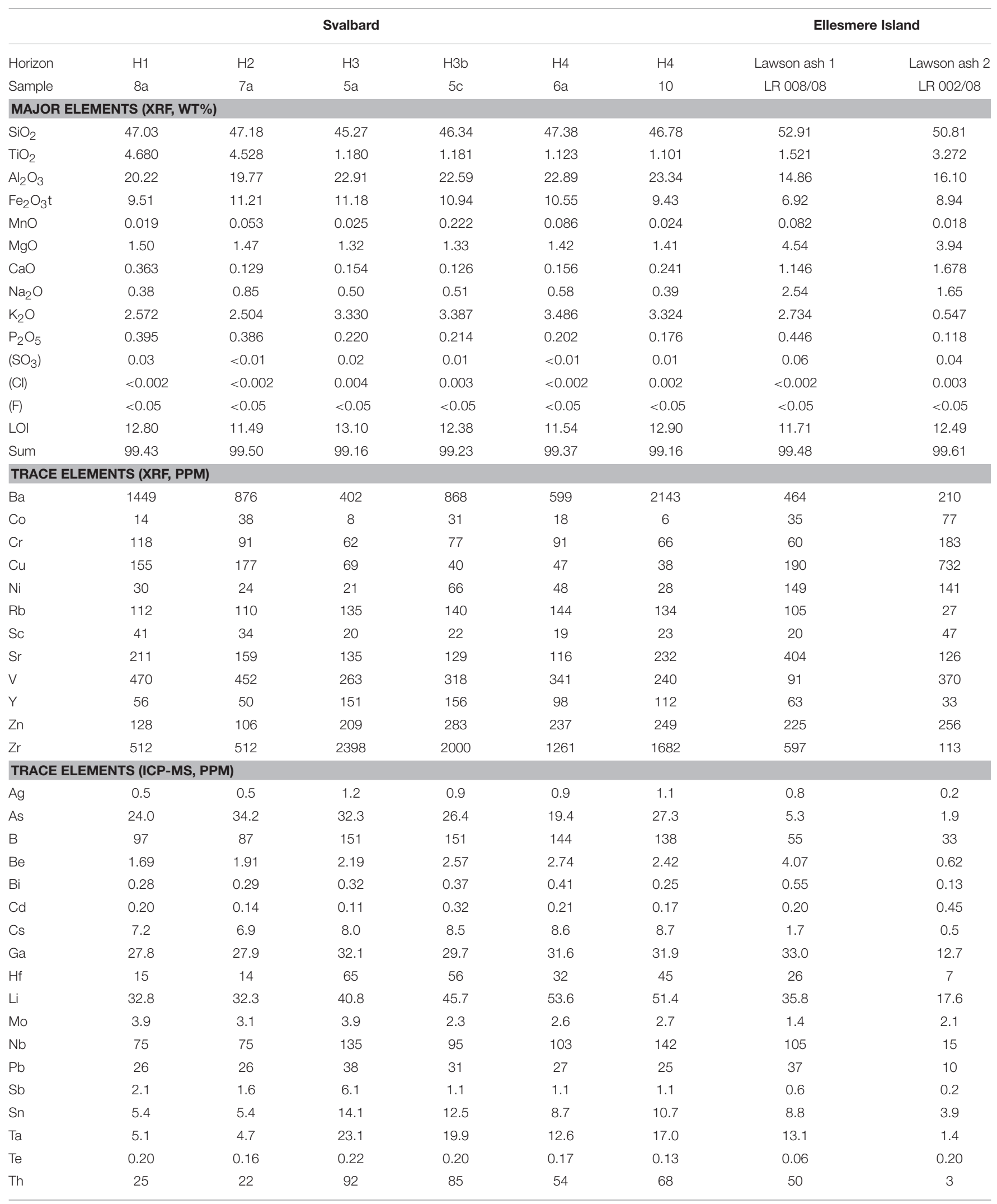




\begin{tabular}{|c|c|c|c|c|c|c|c|c|}
\hline \multirow[b]{2}{*}{$\mathrm{Tl}$} & \multicolumn{4}{|c|}{ Svalbard } & \multirow[b]{2}{*}{0.35} & \multirow[b]{2}{*}{0.34} & \multicolumn{2}{|c|}{ Ellesmere Island } \\
\hline & 0.27 & 0.28 & 0.31 & 0.32 & & & 0.07 & 0.04 \\
\hline U & 7.79 & 5.49 & 10.76 & 8.71 & 8.52 & 9.42 & 9.19 & 2.70 \\
\hline La & 72.4 & 56.2 & 263.6 & 209.9 & 175.4 & 210.2 & 231.0 & 25.0 \\
\hline $\mathrm{Ce}$ & 169.3 & 128.0 & 605.6 & 493.3 & 387.1 & 467.5 & 493.2 & 55.8 \\
\hline $\mathrm{Sm}$ & 17.5 & 11.1 & 39.2 & 33.8 & 26.2 & 31.0 & 32.3 & 6.8 \\
\hline $\mathrm{Eu}$ & 4.7 & 3.0 & 8.1 & 7.3 & 4.7 & 5.5 & 6.7 & 2.0 \\
\hline Gd & 14.7 & 9.5 & 31.6 & 29.7 & 20.9 & 24.0 & 22.1 & 6.8 \\
\hline Tb & 2.1 & 1.5 & 4.9 & 4.7 & 3.2 & 3.6 & 2.8 & 1.0 \\
\hline Dy & 11.3 & 8.7 & 27.3 & 26.5 & 17.6 & 20.4 & 14.3 & 5.8 \\
\hline $\mathrm{Yb}$ & 4.4 & 3.7 & 10.5 & 10.3 & 7.4 & 8.4 & 3.7 & 1.9 \\
\hline Lu & 0.6 & 0.5 & 1.5 & 1.5 & 1.1 & 1.2 & 0.5 & 0.3 \\
\hline
\end{tabular}

LOI, Loss on ignition. See Supplementary Material for whole-rock data.

TABLE 3 | Sm-Nd isotope data of bentonite samples ( $<2 \mu \mathrm{m}$ fractions) from Svalbard and Ellesmere Island.

\begin{tabular}{|c|c|c|c|c|c|c|c|c|}
\hline Horizon & Sample & Sm (ppm) & Nd (ppm) & ${ }^{147} \mathrm{Sm} /{ }^{144} \mathrm{Nd}$ & ${ }^{143} \mathrm{Nd} /{ }^{144} \mathrm{Nd}$ & $\varepsilon \mathrm{Nd}(0)$ & $\varepsilon N d(t)$ & $t_{D M}(G a)$ \\
\hline \multicolumn{9}{|c|}{ SVALBARD, BJøRNDALEN, BASILIKA FORMATION } \\
\hline $\mathrm{H} 1$ & $8 a$ & 18.12 & 91.83 & 0.1193 & 0.512673 & 0.7 & 1.3 & 0.67 \\
\hline $\mathrm{H} 2$ & $7 a$ & 11.46 & 59.91 & 0.1156 & 0.512669 & 0.6 & 1.2 & 0.65 \\
\hline H3 & $5 a$ & 40.26 & 240.13 & 0.1014 & 0.512684 & 0.9 & 1.6 & 0.55 \\
\hline $\mathrm{H} 3 \mathrm{~b}$ & $5 \mathrm{c}$ & 35.07 & 199.31 & 0.1064 & 0.512619 & -0.4 & 0.3 & 0.67 \\
\hline \multicolumn{9}{|c|}{ ELLESMERE ISLAND, SPLIT LAKE, MOUNT LAWSON FORMATION } \\
\hline Lawson ash 1 & LR 008/08 & 33.11 & 212.99 & 0.0943 & 0.512749 & 2.2 & 2.9 & 0.43 \\
\hline Lawson ash 2 & LR 002/08 & 6.98 & 30.48 & 0.1394 & 0.512781 & 2.8 & 3.2 & 0.63 \\
\hline
\end{tabular}

Initial $\varepsilon N d(\varepsilon N d(t))$ calculated with 60 Ma for Basilika Formation bentonites and Lawson ash 1 and 54 Ma for Lawson ash 2.

High loss on ignition (6.5-10.0 wt\%; see Supplementary Material) in all samples and a lack of relict volcanic glass indicate strong alteration of the primary volcanic ashes. The $<2 \mu \mathrm{m}$ fractions were analyzed separately to obtain a more comprehensive characterization of the clay minerals. The clay fractions showed CEC values of 27-35 meq/100 g (H1 and $\mathrm{H} 2$ ) and 24-32 meq/100g (H3 and H4), consistent with a high abundance of clay minerals, but lower than the CECs typical for smectite-rich bentonites (Rollins and Pool, 1968; Reinhardt et al., 2013). XRD analysis of air-dried and ethylene glycol solvated samples revealed that the $<2 \mu \mathrm{m}$ fractions were dominated by illite-smectite type expandable clay minerals, with R0 illite (0.45)-smectite in samples $\mathrm{H} 1$ and $\mathrm{H} 2$ and $\mathrm{R} 1$ illite (0.6)-smectite in samples $\mathrm{H} 3$ and $\mathrm{H} 4$ (Figure 6). This is consistent with previous observations (Dypvik and Nagy, 1978). Furthermore, quartz, kaolinite, and chlorite (Figure 6) were present in all $<2 \mu \mathrm{m}$ fractions, while anatase was abundant in samples $\mathrm{H} 1$ and $\mathrm{H} 2$ (Figure 6). The dominance of illite-smectite in contrast to smectite in other bentonites might be indicative of diagenetic transformation of smectite to illite (Šucha et al., 1993), consistent with the burial history of the CTB (Blythe and Kleinspehn, 1998) and is therefore a further indication of the strong diagenetic alteration of the bentonites.

\section{Geochemical and Isotopic Characterization of the Basilika Formation Bentonites}

To largely exclude detrital contaminants, major and trace element geochemical analyses and $\mathrm{Sm}-\mathrm{Nd}$ isotope ratio measurements were performed using the $<2 \mu \mathrm{m}$ fraction assuming that the clay 


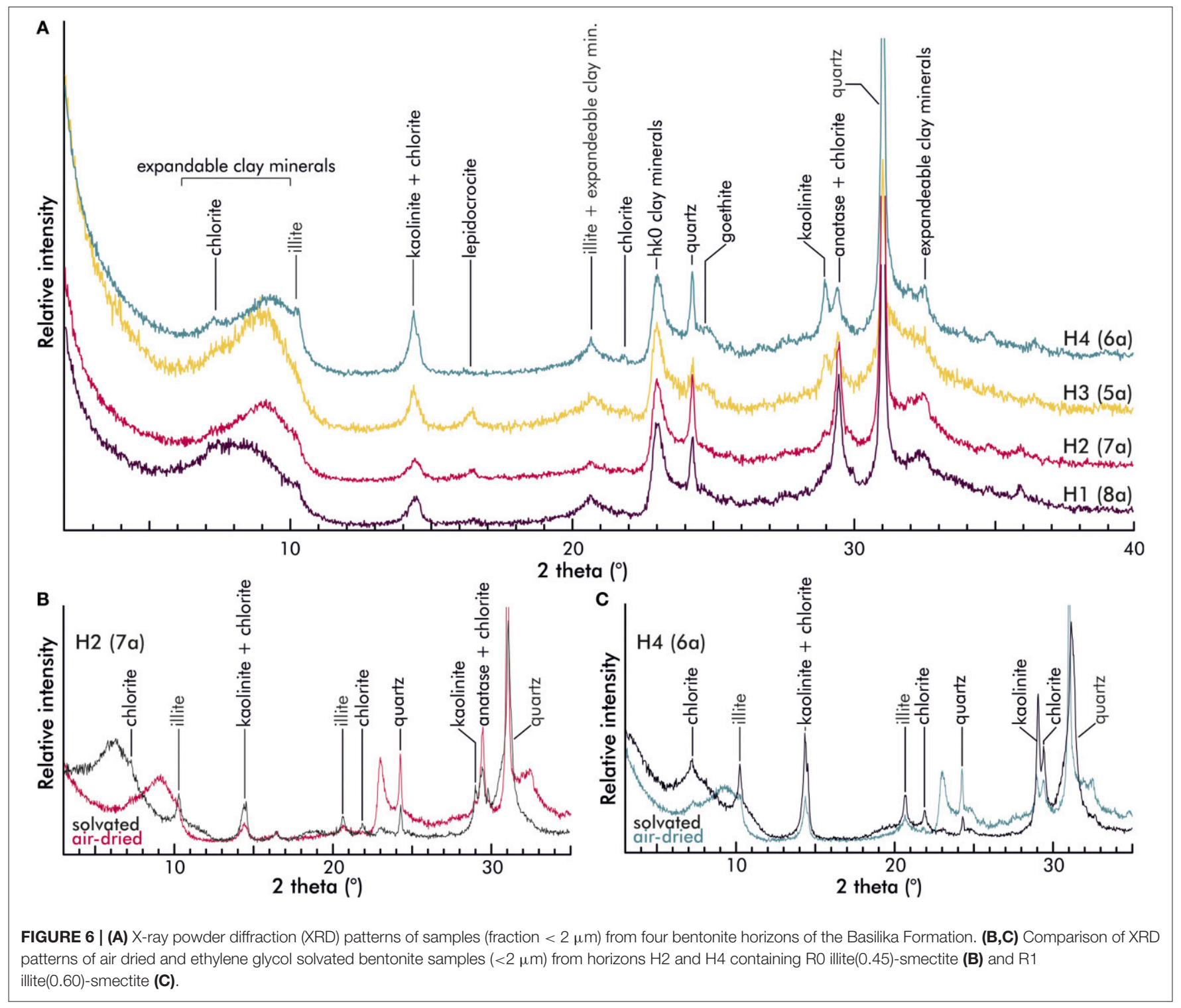

minerals represent the alteration products of the original volcanic glass.

The bentonite samples exhibited similar $\mathrm{SiO}_{2}$ concentrations (45-47 wt\%; Table 2). They can be divided into two groups, a stratigraphically older suite comprising $\mathrm{H} 1$ and $\mathrm{H} 2$ with elevated $\mathrm{TiO}_{2}(\sim 5 \mathrm{wt} \%)$ and lower $\mathrm{Al}_{2} \mathrm{O}_{3}(\sim 20 \mathrm{wt} \%)$ abundances and a younger group comprising $\mathrm{H} 3$ to $\mathrm{H} 4$ with lower $\mathrm{TiO}_{2}(\sim 1 \mathrm{wt} \%)$ and higher $\mathrm{Al}_{2} \mathrm{O}_{3}(\sim 23 \mathrm{wt} \%)$ contents. Furthermore, the $\mathrm{K}_{2} \mathrm{O}$ content is slightly higher in $\mathrm{H} 3$ and $\mathrm{H} 4(\sim 3.5 \mathrm{wt} \%)$ compared to $\mathrm{H} 1$ and $\mathrm{H} 2(\sim 2.5 \mathrm{wt} \%)$. Additionally, $\mathrm{V}, \mathrm{Cu}$, and Sc are higher in $\mathrm{H} 1$ and $\mathrm{H} 2$, whereas $\mathrm{Nb}, \mathrm{Y}, \mathrm{Th}, \mathrm{Zr}$, and the rare earth elements (REE; except $\mathrm{Eu}$ ) are higher in $\mathrm{H} 3$ and $\mathrm{H} 4$ (Supplementary Material).

The geochemical fingerprint of the analyzed bentonites was in part inherited by the parental volcanic ashes but likely also influenced by post-depositional alteration. Alteration may have occurred at several stages. Firstly, alteration by seawater via ion exchange after deposition of the ashes in the pelagic zone of the marine basin, which occupied the CTB during the time of deposition. Subsequently, the volcanic glass and the less stable minerals were transformed to clay and other minerals. Finally, the volcanic ashes may have been altered by diagenesis at a burial depth of up to $2 \mathrm{~km}$, which was followed by Neogene uplift and exhumation as well as recent weathering (Blythe and Kleinspehn, 1998; Dörr et al., 2013; Schlegel et al., 2013). During all of these phases, ions may have been exchanged with the surrounding rocks and water, thus altering the original geochemical fingerprint. Specifically, seawater-mediated alteration of felsic and intermediate volcanic rocks to bentonites may result in leaching of $\mathrm{Na}, \mathrm{K}, \mathrm{Sr}, \mathrm{Rb}$, as well as uptake of $\mathrm{Mg}$ and $\mathrm{Fe}^{2+}$, while $\mathrm{Al}, \mathrm{Ti}, \mathrm{Zr}, \mathrm{Nb}, \mathrm{V}$, and $\mathrm{Ni}$ are residually enriched and the behavior of $\mathrm{Si}$ and $\mathrm{Ca}$ depends on the chemistry of the parent rock (Christidis, 1998). Similarly, seafloor alteration of basaltic ashes may result in enrichment in $\mathrm{Si}$ and $\mathrm{Al}$ as well as depletion in $\mathrm{Fe}, \mathrm{Mg}$, and $\mathrm{Ca}$ (Larsen et al., 2003a). Furthermore, the diagenetic transformation of smectite 
to illite should theoretically yield enrichment in $\mathrm{K}$ and $\mathrm{Al}$ and decrease in $\mathrm{Mg}$ and $\mathrm{Na}$ content, based on the stoichiometry of the montmorillonite and illite end members. Therefore, conventional discrimination diagrams for the characterization of the volcanic source rocks may not be applicable to the classification of bentonites. Still, the strong systematic differences in $\mathrm{TiO}_{2}$ and $\mathrm{Al}_{2} \mathrm{O}_{3}$ content among the Basilika Formation bentonites likely originate from differences in the chemical composition of the volcanic ash precursors and may therefore be characteristic for the magmatic source.

The behavior of the REE and $\mathrm{Y}$ during alteration is controlled by the presence of phosphate minerals (Christidis, 1998; Reinhardt et al., 2013). There is no indication for the presence of such minerals in the Basilika bentonite samples. Furthermore, the concentrations of REE and Y are generally higher in the $<2 \mu \mathrm{m}$ fraction than in the whole-rock fraction (see Supplementary Material) indicating that these elements are hosted by the clay minerals (as most other trace elements, except $\mathrm{Ba}$ and $\mathrm{Sr}$ ). Thus, we infer that the REE and some other relatively immobile trace elements (e.g., $\mathrm{Zr}, \mathrm{Ti}, \mathrm{Y}, \mathrm{Nb}$ ) as well as their ratios can provide a geochemical fingerprint of the parent volcanic ash. The chondrite-normalized REE patterns of the bentonite samples generally show enrichment of light REE (LREE) vs. heavy REE (HREE) with $\mathrm{H} 1$ and $\mathrm{H} 2\left(\mathrm{La}_{\mathrm{n}} / \mathrm{Lu}_{\mathrm{n}}=11-12\right)$ being less enriched than $\mathrm{H} 3$ and $\mathrm{H} 4\left(\mathrm{La}_{n} / \mathrm{Lu}_{\mathrm{n}}=15-19\right)$ (Figure 7). In the range of the HREE, the patterns are subparallel to each other $\left(\mathrm{Tb}_{\mathrm{n}} / \mathrm{Lu}_{\mathrm{n}}=\right.$ $1.9-2.2$ for $\mathrm{H} 1 / \mathrm{H} 2$ and $2.1-2.3$ for $\mathrm{H} 3 / \mathrm{H} 4)$, indicating magma generation under similar conditions with the $\mathrm{H} 3 / \mathrm{H} 4$ magma being more evolved compared to $\mathrm{H} 1 / \mathrm{H} 2$. This is supported by a negative $\mathrm{Eu}$ anomaly increasing from $\mathrm{H} 1\left(\mathrm{Eu} / \mathrm{Eu}^{*}=0.87\right)$ to $\mathrm{H} 4$ $\left(\mathrm{Eu} / \mathrm{Eu}^{*}=0.59\right)$ indicating fractional crystallization of feldspar (Philpotts and Schnetzler, 1968). An alkali-basaltic original ash composition is suggested for the $\mathrm{H} 1$ and $\mathrm{H} 2$ bentonites, while a trachytic to alkali-rhyolitic original ash composition is suggested for the $\mathrm{H} 3, \mathrm{H} 3 \mathrm{~b}$, and $\mathrm{H} 4$ bentonites, assuming that the $\mathrm{Zr} / \mathrm{Ti}$ and $\mathrm{Nb} / \mathrm{Y}$ ratios are only slightly affected by alteration processes
(Figure 8). Thus, the younger bentonites on Svalbard (H3-H4) originated from a more evolved magma than the older bentonites (H1-H2).

The high $\mathrm{Zr}$ concentrations of up to $\sim 2400 \mathrm{ppm}$ in the $<2 \mu \mathrm{m}$ fractions potentially represent a combination of inheritance from the precursor rock and detrital contamination. Since no major $\mathrm{Zr}$-bearing mineral phase could be identified, the $\mathrm{Zr}$ was likely associated with the glass matrix of the precursor rock resulting from rapid cooling before any zircon could crystallize. Likewise, high $\mathrm{Zr}$ concentrations have been observed in melt inclusions in Paleogene alkaline tuffs from Greenland (Heister et al., 2001). In contrast, contamination by detrital zircons during deposition or diagenesis could also lead to elevated $\mathrm{Zr}$ concentrations of the bentonites. However, the interlayered sandstones of the Basilika Formation have up to tenfold lower $\mathrm{Zr}$ concentrations (Schlegel et al., 2013), which are well within the range commonly observed for sedimentary rocks and upper continental crust (Taylor and McLennan, 1985). A detrital origin of the high $\mathrm{Zr}$ concentrations in the $<2 \mu \mathrm{m}$ fractions would thus require extraordinarily strong, selective enrichment of zircon in this size class, which is not commonly observed during diagenesis of sedimentary and magmatic rocks (González López et al., 2005; Taboada et al., 2006; Cavalcante et al., 2014). Contrasting evidence for contamination by detrital zircons comes from the distinct $\mathrm{Zr} / \mathrm{Nb}$ ratios of the bentonites. The high $\mathrm{Nb}$ contents of $\mathrm{H} 1-\mathrm{H} 4$ (75-142) suggest that the bentonites originate from alkaline precursor rocks. Indeed, the $\mathrm{Zr} / \mathrm{Nb}$ ratios of around 7 for $\mathrm{H} 1$ and $\mathrm{H} 2$ are well within the range suggested for alkaline rocks ( $<10$; Larsen et al., 2003a), while those of $\mathrm{H} 3$ and $\mathrm{H} 4(\sim 12-21)$ are far higher. Assuming that $\mathrm{Zr}$ and $\mathrm{Nb}$ are mobile to a similar degree during diagenesis, this would suggest that contamination by detrital zircons is negligible for $\mathrm{H} 1$ and $\mathrm{H} 2$, while up to half or more of the $\mathrm{Zr}$ content in $\mathrm{H} 3$ and $\mathrm{H} 4$ could be derived from detrital material. Accounting for this detrital $\mathrm{Zr}$ would yield lower $\mathrm{Zr} / \mathrm{TiO}_{2}$ ratios for $\mathrm{H} 3 / \mathrm{H} 4$ and would thus suggest a lower degree of magmatic differentiation. However, the $\mathrm{Zr} / \mathrm{TiO}_{2}$ vs. $\mathrm{Nb} / \mathrm{Y}$ discrimination
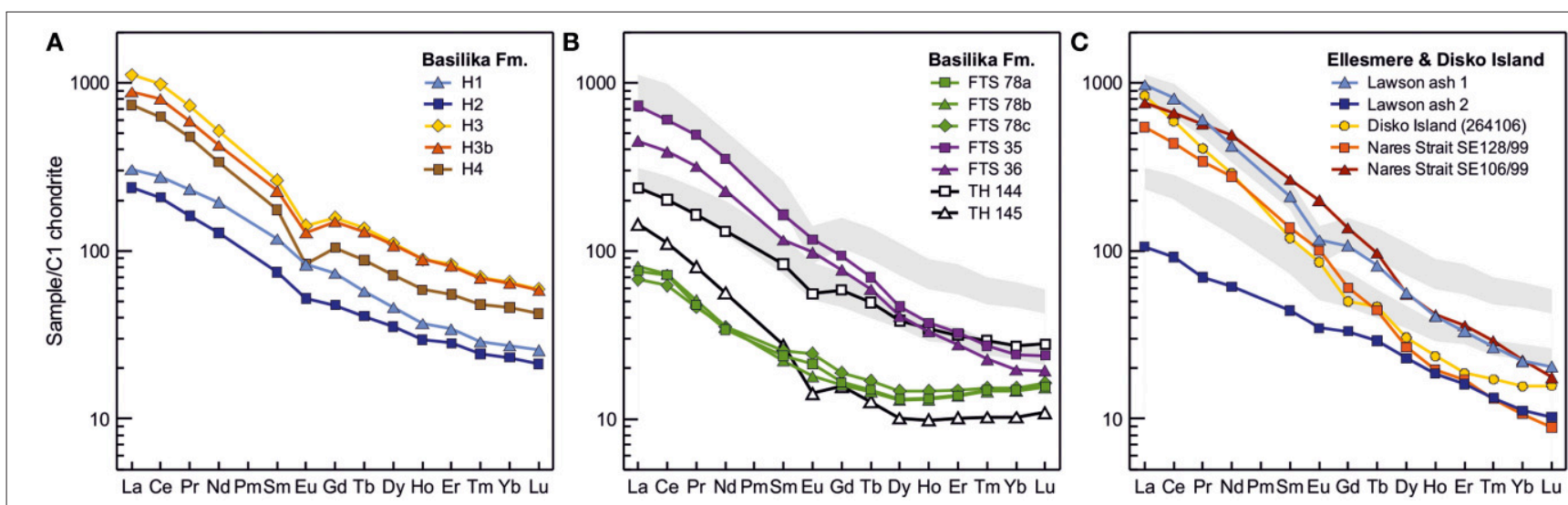

FIGURE 7 | Chondrite normalized rare earth element (REE) patterns (A) of bentonite horizons of the Bjørndalen section (<2 $\mu \mathrm{m}$ fraction) and (B) of bentonites from other outcrops of the Basilika Formation sampled during the CASE 1 expedition (whole rock), and (C) REE patterns of two Paleogene bentonites from the Mount Lawson Formation (Ellesmere Island, $<2 \mu \mathrm{m}$ fraction), alkaline volcanic detritus from the Cape Back Basin, Nares Strait (Estrada et al., 2010), and an alkaline flood basalt from Disko Island (Larsen et al., 2003b) for comparison. REE patterns of the Bjørndalen section bentonites are shaded gray in (B,C). Chondrite data from Sun and McDonough (1989). 


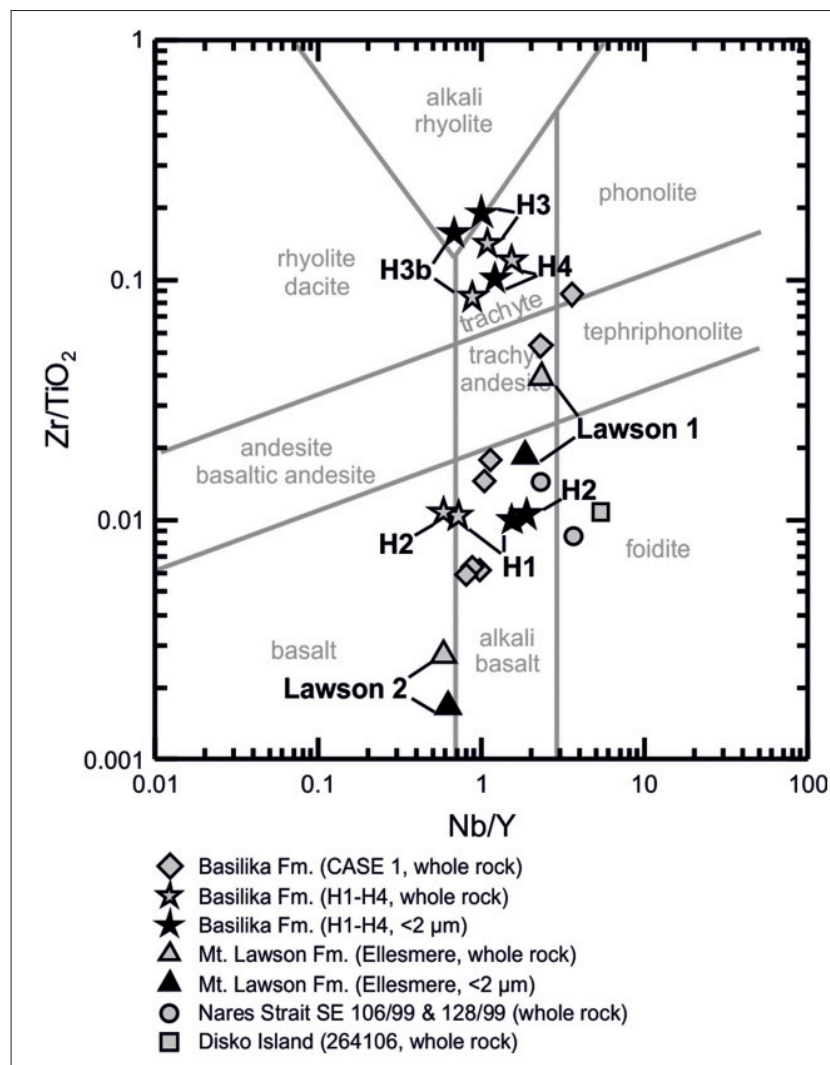

FIGURE 8 | Zr/Ti-Nb/Y discrimination diagram (after Winchester and Floyd, 1977; Pearce, 1996) of Basilika Formation bentonites as well as two Paleogene bentonites from the Mount Lawson Formation (Ellesmere Island; whole-rock data from Reinhardt et al., 2013), alkaline volcanic detritus from the Cape Back Basin, Nares Strait (Ellesmere Island; Estrada et al., 2010) and an alkaline flood basalt from Disko Island (Greenland; Larsen et al., 2003b) for comparison. Black symbols, $<2 \mu \mathrm{m}$ fraction; Gray symbols, whole rock.

diagram would still indicate that $\mathrm{H} 3 / \mathrm{H} 4$ originate from a more evolved magma than $\mathrm{H} 1 / \mathrm{H} 2$ even when accounting for a large degree of contamination by detrital $\mathrm{Zr}$ of $50 \%$ or more.

The different enrichment of LREE vs. HREE in $\mathrm{H} 1 / \mathrm{H} 2$ and $\mathrm{H} 3 / \mathrm{H} 4$ likely reflects different degrees of partial melting of the mantle source. A similar mantle source is supported by the Sm$\mathrm{Nd}$ isotope data (Table 3). The $\varepsilon \mathrm{Nd}(\mathrm{t})$ values of $\mathrm{H} 1 / \mathrm{H} 2(1.2-1.3)$ and $\mathrm{H} 3 / \mathrm{H} 4(0.3-1.6)$ overlap and the $\mathrm{Nd}$ model ages $\left(\mathrm{t}_{\mathrm{DM}}\right)$ vary in a narrow range for all horizons $(0.55-0.67 \mathrm{Ga})$. This mantle source is very similar to those of alkaline basalts from ocean island and continental rifting settings (Wilson, 1989), pointing to either a fertile mantle source as in hot-spot settings, melting in the subcontinental lithospheric mantle and/or the contamination of the magma by continental crust. Overall, the REE data of the $\mathrm{H} 1-\mathrm{H} 4$ bentonites suggest that all analyzed ash layers were sourced from the same tectono-magmatic setting and possibly also from the same volcanic center within a continental rift zone, exhibiting minor differences in the parental magma composition and different degrees of differentiation.

Based on the $\mathrm{Zr} / \mathrm{Ti}-\mathrm{Nb} / \mathrm{Y}$ discrimination diagram, the CASE 1 bentonites originate from an alkaline magmatic suite (Figure 8).
Their whole-rock REE can be subdivided into two groups: A group with highly enriched LREE vs. HREE and a group with less enriched LREE vs. HREE and a trough in the HREE from Tb to $\mathrm{Lu}$ that is probably the result of stronger alteration (Figure $7 \mathrm{~B}$ ). The REE patterns of the second group actually look similar to pelitic sediments, but the positive $\varepsilon_{\mathrm{Nd}}(\mathrm{t})$ value of sample TH 145 and the small positive Eu anomalies of the FTS 78 samples point to a volcanic origin. The small positive $\mathrm{Eu}$ anomalies point to a source in North Greenland or northeastern Ellesmere Island (Thorarinsson et al., 2011a; Estrada, 2015). The REE patterns of the FTS 35-36 samples (Erdmannflya) are similar to those of the geochemically evolved Bjørndalen bentonites $\mathrm{H} 1$ and $\mathrm{H} 4$, but are steeper. The REE pattern of sample TH 144 is comparable to those of $\mathrm{H} 3$ and $\mathrm{H} 4$, but the $\mathrm{Sm}-\mathrm{Nd}$ data of this sample $\left[\varepsilon_{\mathrm{Nd}}(\mathrm{t})=-0.9 ; \mathrm{t}_{\mathrm{DM}}=0.9 \mathrm{Ga}\right]$ indicate stronger contamination with crustal materials or potentially a different mantle source. Thus, the bentonite layers sampled during CASE 1 cannot be considered to be equivalents of the Bjørndalen bentonites, although they originate most likely also from continentalrift related magmatism. The geochemical fingerprints of the CASE 1 samples indicate that different volcanic centers may have sourced the various bentonite layers within the Basilika Formation.

\section{Results of Zircon U-Pb Dating}

All four samples from the Basilika Formation yielded similar zircon populations consisting mostly of subrounded and rounded zircon that varied from colorless to pale violet. Euhedral grains were rare and tended to be small. U-Pb LA-ICP-MS analyses were performed on a total of 430 zircons from the four bentonite horizons (Supplementary Material). The 261 zircon age analyses with $\leq 10 \%$ central discordance were used for further interpretation (Figure 9). Age distributions were highly similar between the four samples from the Basilika Formation, indicating constant sediment sources during deposition (Figure 10). The zircon ages with $<10 \%$ discordance span a range from $88 \pm$ $1 \mathrm{Ma}$ to $2950 \pm 10 \mathrm{Ma}$ (Supplementary Material) that can be subdivided into four distinct populations (Figure 10):

(i) Neoarchean (2500-2800 Ma) with a peak at 2700-2800 Ma;

(ii) Paleoproterozoic (1700-2100 Ma) with a peak around 1800-1900 Ma;

(iii) a small population at ca. $900-1000 \mathrm{Ma}$ (8 of 11 ages between $974 \mathrm{Ma}$ and $995 \mathrm{Ma})$;

(iv) a broad cluster of ages scattered fairly uniformly between 200 and $650 \mathrm{Ma}$.

Only a few scattered ages $<200 \mathrm{Ma}$ are present $(88 \pm 1$, $152 \pm 1,154 \pm 2,162 \pm 1,188 \pm 3 \mathrm{Ma}$ ), all older than the Paleocene depositional age of the Basilika Formation. The pale violet grains are mostly Precambrian in age. The euhedral grains show a similarly wide age range as the subrounded ones, although the youngest grains are mostly euhedral. Thus, morphology cannot be used as a discriminant for primary volcanic zircons. Th/U profiles for many of the younger grains show a characteristic, step change from low to high ratios that might indicate the presence of core-overgrowth relationships. Therefore, LA-ICP-MS profiles were measured 

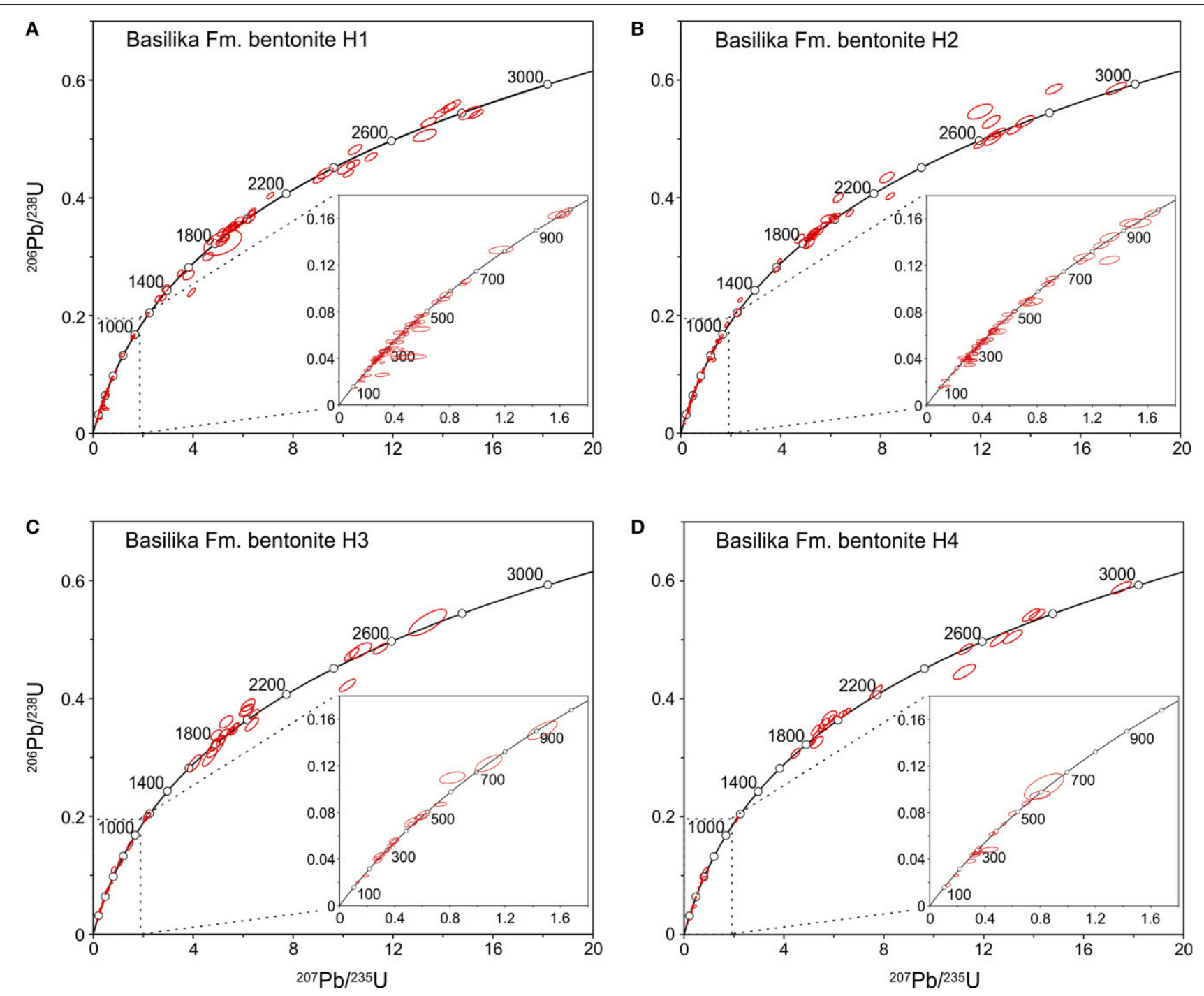

FIGURE 9 | Concordia diagrams of LA-ICP-MS U-Pb analyses of zircons from four bentonite horizons (H1-H4, panels A-D) of the Basilika Fm. Error ellipses represent 95\% confidence limits.

over a single component where possible, but in some cases ages may represent mixtures of Neoproterozic and Phanerozoic components.

Only 18 concordant zircon ages were detected in the Ellesmere Island samples, which cluster around 1800-2000, 2500-2900 $\mathrm{Ma}$, with minor age groups around 1500-1700 and 1000-1200 Ma (Figure 11). Mesozoic/Paleozoic ages are almost completely absent.

\section{DISCUSSION}

\section{Potential Volcanic Sources of Basilika Formation Bentonites}

Due to stratigraphic constraints, the interval of $\sim 62-58 \mathrm{Ma}$ is a realistic estimate for the depositional age of the Basilika Formation and the volcanic ashes. This volcanic activity predates the main phase of the NALIP around 55-50 Ma, which produced the ash layers widespread in the North Atlantic region (Figure 1; Tsikalas et al., 2002; Larsen et al., 2003a; Storey et al., 2007; Tegner et al., 2011), but it is temporally related to the initial phase of the NALIP at around $61 \mathrm{Ma}$ and several alkaline volcanic events in the high Arctic (Figure 1).

The initial phase of the NALIP is expressed mainly as tholeiitic intrusives and flood basalts on the British Isles, East Greenland, Baffin Island and West Greenland including Disko Island, and is related to continental rifting to the east and west of Greenland (Storey et al., 2007). The REE patterns of the Basilika Formation bentonites show no resemblance to those of the tholeiites, but they fit well to the REE signatures of alkaline basalts from Disko Island (Figure 7; Larsen et al., 2003b; Larsen and Pedersen, 2009). However, the NALIP is unlikely to have sourced the Basilika Formation bentonites as the initial phase of the NALIP 


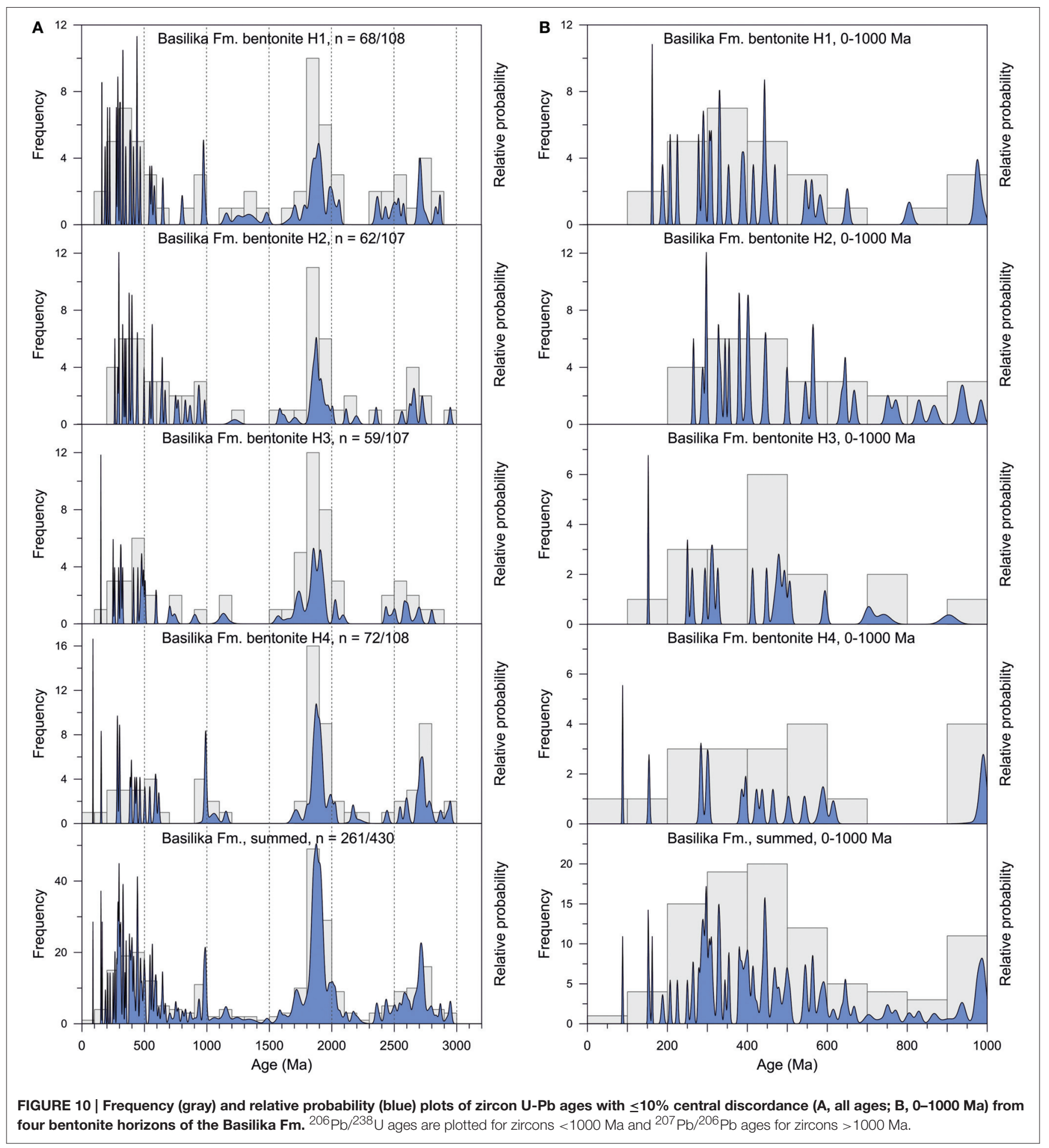

was not commonly associated with explosive activity (O’Nions and Clarke, 1972; Thompson, 1982; Storey et al., 1998; Larsen and Pedersen, 2009). The only evidence for early Paleocene explosive volcanism related to the NALIP are $\sim 58 \mathrm{Ma}$ old basalt tuffs from the Svartenhuk Formation in the Nuussuaq basin of western Greenland. However, the REE patterns of the Svartenhuk Formation basalts (Larsen et al., 2016) do not resemble those of the bentonites from the Basilika and Mount Lawson formations.

Instead, some of the REE patterns of the Basilika Formation bentonites correlate relatively well with those of Lawson-ash 1, which was deposited on southern Ellesmere Island at $\sim 60$ 


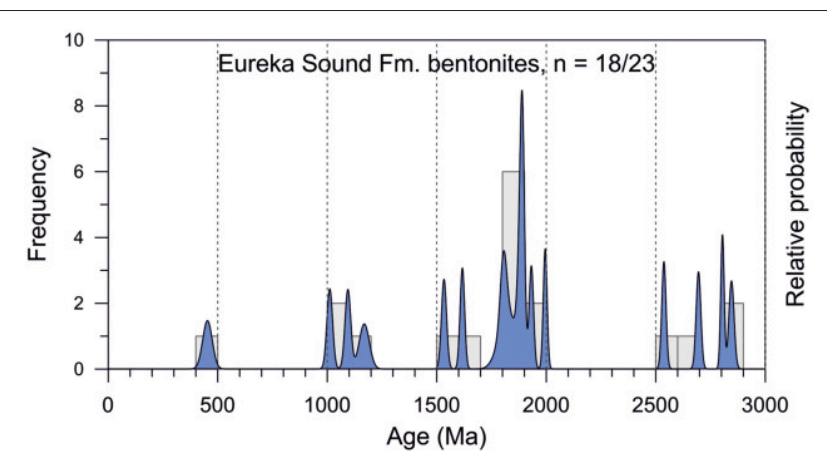

FIGURE 11 | Frequency (gray) and relative probability (blue) plots of zircon $\mathrm{U}-\mathrm{Pb}$ ages with $\leq 10 \%$ central discordance from two bentonite horizons (Lawson ash 1 and 2) of the Mount Lawson Formation, Ellesmere Island. ${ }^{206} \mathrm{~Pb} / 238 \mathrm{U}$ ages are plotted for zircons $<1000 \mathrm{Ma}$ and ${ }^{207} \mathrm{~Pb} /{ }^{206} \mathrm{~Pb}$ ages for zircons > $1000 \mathrm{Ma}$.

Ma (Figure 7; Reinhardt et al., 2013), both showing steep REE patterns with strong enrichment in LREE over HREE and small negative $\mathrm{Eu}$ anomalies. Additionally, Lawson-ash 1 and the Basilika Formation bentonites show broadly similar major element composition but some differences in $\mathrm{MgO}, \mathrm{Na}_{2} \mathrm{O}$, and $\mathrm{SiO}_{2}$ contents (Table 2), which may have been caused by different degrees of alteration.

The REE patterns of some of the Basilika Formation bentonites as well as Lawson-ash 1 broadly resemble those of the evolved members of the Kap Washington Group on North Greenland as well as volcanic detritus in the Cape Back Basin near Nares Strait on Ellesmere Island (Estrada et al., 2010; Thorarinsson et al., 2011a). The Kap Washington Group comprises a $5000 \mathrm{~m}$ thick suite of bimodal, basaltic to rhyolitic rocks, which was emplaced between 71 and $61 \mathrm{Ma}$ (Brown et al., 1987; Estrada et al., 2001; Tegner et al., 2011; Thorarinsson et al., 2011a,b). The evolved phase of the Kap Washington Group was associated with explosive volcanism producing tuffs, ignimbrites, and pyroclastic sandstones (Brown et al., 1987; Thorarinsson et al., 2011a) and may potentially have sourced part of the bentonites on Svalbard and Ellesmere Island. In this case, the time of deposition of Lawson-ash 1 would need to coincide with the last volcanic activity on northern Greenland, which can be reconciled only if the maximum errors of age determinations are considered (Reinhardt et al., 2013). Moreover, the initial $\varepsilon N d(t)$ values of Lawson-ash $1[\varepsilon \mathrm{Nd}(60)=2.9]$ exclude a provenance from the evolved phase of the Kap Washington Group $[\varepsilon \mathrm{Nd}(70)$ $<1$ ]. Similarly, the $\varepsilon \mathrm{Nd}(60)$ values of the Basilika Formation bentonites $(0.3-1.6)$ are higher than or within the upper range of the most positive $\varepsilon \mathrm{Nd}(\mathrm{t})$ values observed in evolved rocks of the Kap Washington Group (Estrada and Henjes-Kunst, 2004; Thorarinsson et al., 2011a).

The alkaline volcanic detritus from the Cape Back basin, originating from ignimbrites and lava flows produced between 61 and $58 \mathrm{Ma}$, exhibits REE patterns that resemble those of Lawsonash 1 and parts of the Basilika Formation bentonites (CASE 1 samples FTS35-36) including the lack of a negative Eu anomaly (Figure 7; Estrada et al., 2010). Additionally, the $\varepsilon \mathrm{Nd}(\mathrm{t})$ values of both Lawson ash 1 and the Basilika Formation bentonites fall into the wide range of $\varepsilon \mathrm{Nd}(\mathrm{t})$ values of the Cape Back basin detritus. Given the close temporal and paleogeographic proximity, it is plausible that the volcanic detritus of the Cape Back basin and parts of the bentonite layers from Svalbard and Ellesmere Island share a common, alkaline, continental rift-related source and potentially originate from the same volcanic center (Estrada et al., 2010).

The dating of Lawson-ash 2 from Ellesmere Island was associated with relatively high uncertainties, but if the preliminary age of $53.90 \pm 3.1 \mathrm{Ma}$ (Reinhardt et al., 2013) is correct, it would postdate the Basilika Formation bentonites and the youngest known alkaline volcanic suite in the High Arctic at Bathurst Island ( 56 Ma; Day et al., 2005). The Lawson-ash 2 bentonite layer shows significantly less enrichment in LREE (Figure 7) and seems geochemically and temporally related to the later, major phase of the NALIP. Similar to coeval ash deposits in the North Atlantic Ocean (Figure 1; cf. Larsen et al., 2003a), this ash may have emanated from volcanic centers in eastern Greenland (Heister et al., 2001) or western Greenland (Thompson, 1975; Saunders et al., 1997; Larsen et al., 2016), and might be causally linked to the occurrence of early Eocene bentonites in the Frysjaodden Formation in the CTB of Svalbard (cf. Charles et al., 2011).

In conclusion, the Paleocene bentonites on Svalbard and Ellesmere Island fit well into the emerging view of widespread continental rift-related alkaline volcanism in the Canadian High Arctic and North Greenland that predates the almost simultaneous start of spreading in the Eurasia Basin, Baffin Bay, and the North Atlantic Ocean. This volcanism was possibly originally of a larger extent than it can be assumed from the preserved volcanic centers, i.e., the outcrops of the ca. $80 \mathrm{Ma}$ old Hansen Point Volcanic Complex on northwestern Ellesmere Island (Estrada and Henjes-Kunst, 2004, 2013) and the 71-61 Ma old Kap Washington Group of North Greenland (Tegner et al., 2011; Thorarinsson et al., 2011b). This volcanic phase is furthermore recorded by the $\sim 61-58$ Ma old volcanic detritus in Paleocene basins (Cape Back Basin) on northeastern Ellesmere Island (Figure 1; Estrada et al., 2010) and $\sim 58$ Ma old tuffs in the Nuussuaq basin in western Greenland (Larsen et al., 2016).

\section{Provenance of Detrital Zircons in the Basilika Formation Potential Sources of Detrital Zircons in the Basilika Formation}

The dominant zircon age populations of the Basilika Formation bentonites imply contributions of cratonic sources to the Paleoproterozoic (1800-1900 Ma) and the smaller Neoarchean (2700-2800 Ma) populations, as well as from Uralian, Caledonian and Timanian sources and probably the Siberian trap volcanism to the 200-650 Ma population. A characteristic feature of the Basilika Formation is the almost complete lack of Grenville-aged and older Mesoproterozoic-aged grains (apart from a small early Neoproterozoic population of 900-1000 Ma).

Rocks with Caledonian, late Grenvillian and Paleoproterozoic to Archean ages are exposed today on northern and westernmost Svalbard (Figure 2). Northern Svalbard has experienced 
continuous erosion during the Jurassic to Cretaceous, followed by fault-related Late Cretaceous to Early Paleocene exhumation and erosion mainly in NE Spitsbergen. Thus, northern Svalbard potentially shed detritus toward the south during the Paleocene (Dörr et al., 2012). Potential cratonic sources in western $\mathrm{Ny}$ Friesland comprise ca. $1750 \mathrm{Ma}$ old granitic orthogneisses, $2709 \pm 28$ Ma old quartz-monzonite and metasediments with Paleoproterozoic (1870-2040 Ma) and Neoarchean detrital zircon ages (Hellman et al., 1997, 2001). Detrital zircons from another related metasedimentary unit, the Smutsbreen Formation of southwestern Ny Friesland, yielded single zircon $\mathrm{Pb}$-evaporation plateau ages of 2560-2680 Ma, but also of ca. 1200-1300 and 1560-1710 Ma (Gee and Hellman, 1996), i.e., in a range that is not typical for the Basilika age spectrum. Caledonian granitoids, known from Nordaustlandet and the Northwestern Basement Province, can contribute 410-450 $\mathrm{Ma}$ old zircons. Further, Grenvillian granites, known from Nordaustlandet and the Northwestern and Southwestern Basement provinces, were intruded at ca. 930-960 Ma (e.g., Johansson et al., 2004, 2005; Gasser, 2014, references therein). However, both the Grenvillian and Caledonian granites have intruded metasedimentary rocks with abundant zircon ages in the range of 1000-1800 Ma (e.g., Pettersson et al., 2009, 2010; Lorenz et al., 2012; Gasser and Andresen, 2013). A selective erosion of the granitoids without the country rocks is very unlikely, unless such an intrusive body has experienced a stronger exhumation as part of a fault-bounded block.

Reworking of Mesozoic sediments surrounding the CTB may represent an alternative source for the detrital zircons in the Basilika Formation. Mesozoic sediments have covered the whole of Svalbard up to the onset of uplift of northern Svalbard and the formation of the West Spitsbergen Fold-and-Thrust Belt (e.g., Smelror et al., 2009). These rocks also covered large areas of the northern and north-eastern Barents Shelf, where uplift and erosion took place probably already since the end of the Early Cretaceous, expressed by a regional unconformity between Aptian-Albian and Paleocene strata and missing Upper Cretaceous sediments on Svalbard (e.g., Smelror et al., 2009; Dallmann, 2015). Mesozoic sediments exposed in central and southern Svalbard comprise Triassic to Lower Cretaceous strata. Detrital zircon age spectra of these sediments, reported by Pózer Bue and Andresen (2014), differ strongly from those of the Basilika Formation. The characteristic 1800-1900 and 2700-2800 Ma populations of the Basilika Formation are absent or only scarcely present in Late Triassic and Early Jurassic formations. Instead these formations are dominated by zircon ages in the range of 200-500 Ma. In contrast, the other Mesozoic formations contain the 1800-1900 and 2700-2800 Ma age populations, but additionally abundant $1100-1600 \mathrm{Ma}$ zircon ages, which are not typical for the Basilika Formation. In summary, reworking of and mixing between Mesozoic formations of Svalbard combined with sediment input from uplifting Caledonian and pre-Caledonian sources in northern Svalbard cannot produce the zircon age spectrum of the Basilika Formation.

Another possibility is a western provenance as indicated by similarities between the detrital zircon age spectra of the Basilika
Formation (Figure 10) and the Mount Lawson Formation from southern Ellesmere Island (Figure 11). The source area for the Mesoproterozoic to Neoarchean zircons in the Mount Lawson Formation is presumably the Canadian-Greenland Shield. However, similar to the cratonic rocks of North Svalbard, the Canadian-Greenland Shield provides not only Neoarchean to Paleoproterozoic zircon ages, but also abundant zircon ages in the range of ca. 1000-1500 Ma (Røhr et al., 2008; Kirkland et al., 2009), which in turn rarely occur in the Basilika Formation. This makes a westerly source of the Basilika sediments unlikely, and points toward an easterly provenance (Figure 12).

Surprisingly, the best fit is with detrital zircon age spectra of sediments from northern Siberia, which are exposed in the Verkhoyansk Fold-and-Thrust Belt, the South Anyui Zone, Chukotka, and the New Siberian Stolbovoi Island (Miller et al., 2006, 2008; Prokopiev et al., 2008; Soloviev and Miller, 2014). The Verkhoyansk Fold-and-Thrust Belt contains a $15-\mathrm{km}$-thick Carboniferous to Jurassic sequence that was deposited along the eastern passive margin of the Siberian craton and deformed during the collision with the Kolyma-Omolon superterrane in the Late Jurassic (Prokopiev et al., 2008). Late Carboniferous to Middle Jurassic sediments from Verkhoyansk show detrital zircon age spectra that are characterized by populations from 250 to $700 \mathrm{Ma}$ (with peaks at around 300, 400, and 480-500 $\mathrm{Ma}$ ), from 1800 to $2100 \mathrm{Ma}$, a small population from ca. 2400 to $2800 \mathrm{Ma}$, and a hiatus between 900 and $1600 \mathrm{Ma}$ (Miller et al., 2006; Prokopiev et al., 2008). The Middle Jurassic sediments bear additional small populations with peaks at 176 and 229 Ma (Prokopiev et al., 2008). Late Jurassic to Early Cretaceous sediments from the South Anyui Zone, Stolbovoi Island and Chukotka have very similar zircon age spectra (Miller et al., 2008). The 250-330 Ma ages, the early Paleozoic ages and the Paleoproterozoic ages in the Verkhoyansk sediments can be linked to intrusive rocks in mountain belts in the Baikal region, from where the detritus was transported by large river systems toward the Verkhoyansk passive margin (Miller et al., 2006; Prokopiev et al., 2008). The youngest ages can be correlated with the Main Granitoid Belt of the Verkhoyansk Fold-andThrust Belt formed during collision-related arc magmatism between 143 and $160 \mathrm{Ma}$ (U-Pb SHRIMP zircon data; Akinin et al., 2009). These ages fit also well with the youngest ages of the Basilika Formation age spectrum. However, how likely is sediment transport from such remote areas to Svalbard over a distance of about $3000 \mathrm{~km}$ during the Paleocene?

\section{Sediment Transport Pathways in the Arctic during the Early Paleocene}

For the present-day Arctic configuration, coarse-clastic sediment transport from the river mouths along the Siberian coast toward the Fram Strait is possible by sea ice, following the Transpolar Drift (Krylov et al., 2008; Thompson et al., 2012). However, perennial sea ice cover and current conditions including the Beaufort Gyre and the Transpolar Drift were likely established during the Miocene (Krylov et al., 2008; Thompson et al., 2012). During the Paleogene, the Arctic Ocean was a much more enclosed basin with only restricted exchange toward the North Atlantic (Thompson et al., 2012). There is, however, 

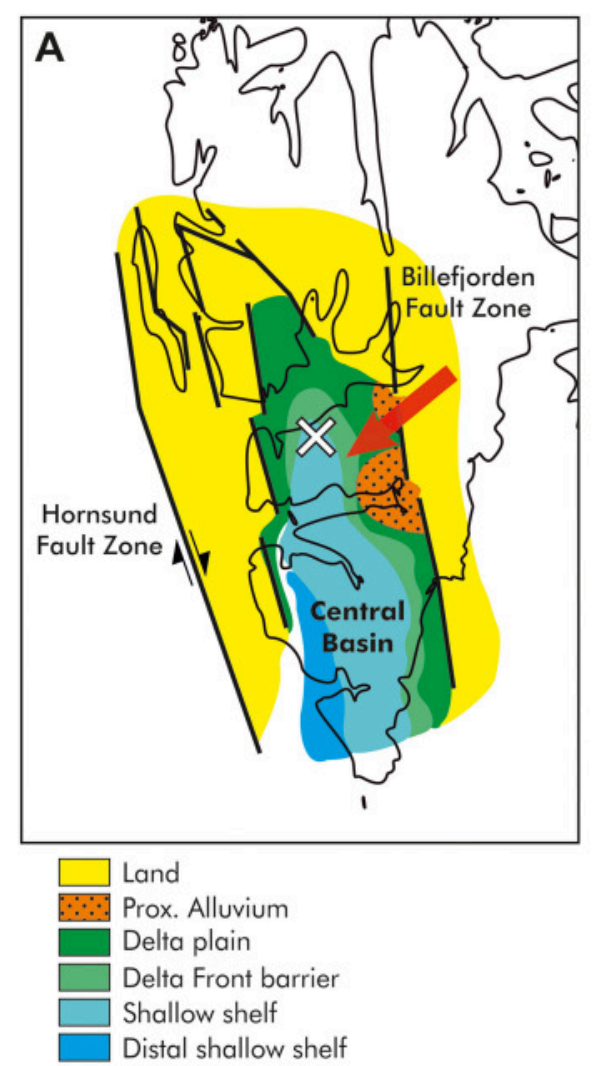

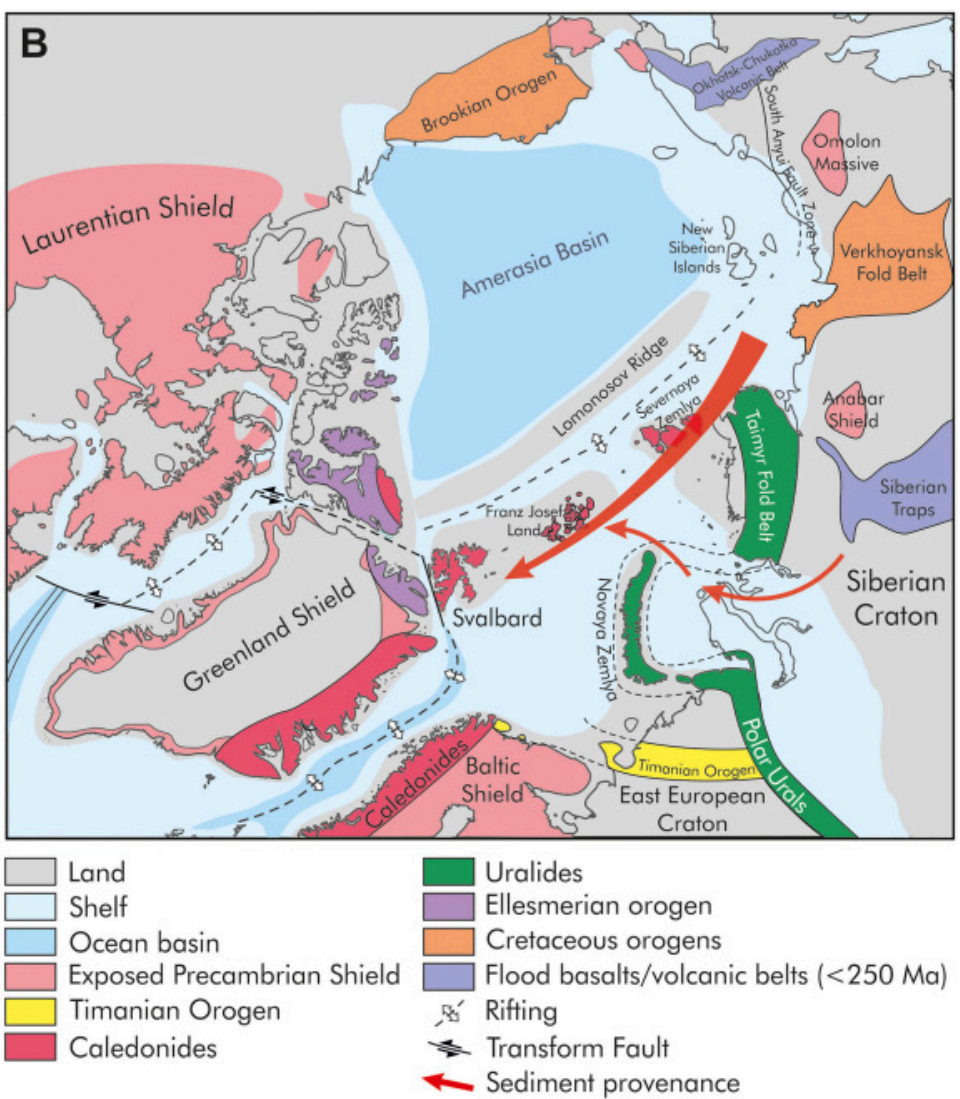

FIGURE 12 | Paleogeography of Svalbard (A) and the surrounding regions (B) during the Paleocene before the onset of seafloor spreading in the Eurasia Basin, North Atlantic and Baffin Bay (A: after Worsley, 1986; B: after Scotese, 2001; Torsvik et al., 2002; Coward et al., 2003; Gee et al., 2006; Omma et al., 2011; Seton et al., 2012; Piepjohn et al., 2013). Red arrows show inferred provenance of detrital zircons. Sampling location indicated by white cross in (A). For further explanation see discussion in the text.

increasing evidence for earlier Arctic glaciation periods (e.g., Moran et al., 2006; Tripati et al., 2008; Immonen, 2013), and the Basilika Formation contains erratics, glendonite (a cold climate indicator), as well as dropstones (Spielhagen and Tripati, 2009, and own field observations), which suggests episodic cold periods with at least seasonal sea ice, intermittent with warmer periods (Spielhagen and Tripati, 2009). Thus, transport of the Basilika detritus from Siberia toward the west by sea ice following similar pathways as today cannot be completely ruled out, but the observed phenomena may hint also to a seasonal, more local ice transport.

Another option would be a transport by (possibly alongshore) currents, which redistributed sediments from Siberia toward the Paleocene position of Svalbard, then still located somewhere north of Greenland (Figure 12). Little is known about the current system at that time. Sediment pathways may have followed the area between the rising northern edge of the Barents Shelf and the Lomonosov Ridge. The latter was presumably exposed above sea level during the Paleocene and Late Cretaceous, as indicated by a pronounced unconformity between ca. 80 and $56 \mathrm{Ma}$ (O'Regan et al., 2008 and references therein), and thus formed a barrier for sediment currents from the Siberian coastal areas against the
Amerasia Basin (Figure 12B). However, this scenario appears unlikely as the uplift of the northern edge of the Barents Shelf would also prohibit sediment transport toward the CTB in the South-West.

A third possibility is that the Basilika Formation clastics of "Siberian origin" were transported to the CTB in several steps including intermediate storage in Mesozoic sediments of the northeastern Barents Shelf. Indeed, an easterly (Uralian and Timanian) provenance has been suggested earlier for Paleozoic detrital zircons in Late Triassic strata on Svalbard and in the Sverdrup Basin (Pózer Bue and Andresen, 2014; Anfinson et al., in press). In this context it should be noted that (i) Mesozoic sediments exposed east of Svalbard (Franz Josef Land) display different detrital age patterns than those exposed on Svalbard, and do NOT contain the Grenvillian ages characteristic for the "westerly" provenance of most of the Svalbardian Mesozoic sediments (Soloviev et al., 2015); and (ii) that Mesozoic sediments of the Barents Sea underwent extensive erosion during the Paleocene, as evidenced, amongst others, by Triassic, Jurassic and Early Cretaceous sediments subcropping over wide areas of the northeastern Barents Shelf beneath the actual seafloor (e.g., Asch, 2005). 
Thus, Mesozoic sediments originally sourced from the Verkhoyansk Fold-and-Thrust Belt and mixed with clastic detritus derived from the Siberian traps, the Uralides and the Timanides may have been reworked and redeposited during the Paleocene (Figure 12B). However, a convincing answer regarding transport mechanisms across the Arctic including larger scale fluvial drainage patterns will only be possible when more data become available, both on the provenance of clastic sediments and the Paleogene climate evolution of the Arctic.

In any case, it is striking that the Basilika Formation apparently received only little detritus from the immediate surroundings, including the Mesozoic sediments presently exposed directly east of the CTB, the area of the present West Spitsbergen Fold-and-Thrust Belt toward the west, and northern Svalbard, which was emergent and underwent erosion during the Paleocene (Dörr et al., 2012). Only the small late Grenvillian age group contained in the Basilika sediments seems to be derived from local sources, most likely from the Newtontoppen area toward the north, which was relatively rapidly exhumed during the Paleocene (Dörr et al., 2012; the Newtontoppen is the highest peak of present-day Svalbard, consisting of a Caledonian granitic body intruded into Proterozoic metamorphic rocks). The paucity of local detritus implies that the West-Spitsbergen Fold-and-Thrust Belt was still not active, in agreement with previous assumptions (Tessensohn and Piepjohn, 2000), and that the Mesozoic cover, today exposed east of the CTB, was still an area of deposition rather than of erosion. Higher subsidence rates occurred in the Eocene, when the West Spitsbergen Fold-and-Thrust Belt became active, and sediment transport changed from an easterly to a westerly source area (HellandHansen, 1990; Bruhn and Steel, 2003). The lack of local detritus also implies that the contribution from North Svalbard was either minor and thus strongly diluted by the dominant eastern source (in agreement with relatively low erosion rates reported for North Svalbard; Dörr et al., 2012), or that North Svalbard was drained toward the North into the assumed lowland between Svalbard and the Lomonosov Ridge, with the local drainage divide presumably located in the Newtontoppen area.

\section{CONCLUSIONS}

In this study we investigated the characteristics of bentonite layers contained in the Paleocene Basilika Formation, as well as the provenance of their clastic host rocks. Bentonite layers were sampled from the lower and upper parts of the Basilika Formation in the Bjørndalen area on central Spitsbergen. For geochemical comparisons, additional bentonite samples from the Basilika Formation taken during the CASE 1 expedition of BGR in 1992 and two samples from the Lower Paleogene Mount Lawson Formation of Ellesmere Island (Canadian Arctic) were included.

From our data we draw the following conclusions:

(i) The four analyzed bentonite layers from Bjørndalen represent altered volcanic ashes that originate from a common mantle source, but with different degrees of partial melting and having experienced different fractionation. The older layers are less evolved than the younger layers and were derived from an alkali-basaltic parental magma, whereas the younger layers were derived from a trachytic to alkali-rhyolitic precursor.

(ii) The geochemical fingerprints of the CASE 1 bentonite samples show similarities with, but also differences to, the Bjørndalen bentonites, which renders an origin of all Basilika bentonites from a common volcanic center unlikely. However, some of the CASE 1 samples may share a common source with the volcanic detritus from the Nares Strait area (Estrada et al., 2010).

(iii) The Basilika Formation bentonites, the $\sim 60$ Ma bentonite layer on Ellesmere Island (Lawson-ash 1; Reinhardt et al., 2013) and the 61-58 Ma volcanic detritus in the Nares Strait area (Estrada et al., 2010) all originate from alkaline, continental-rift magmatism related to the last, explosive stages of the HALIP. This magmatism was probably more widespread in the Arctic during the Paleocene than it can be assumed from the present-day extent of volcanites (e.g., the 71-61 Ma Kap Washington Group of North Greenland; Tegner et al., 2011; Thorarinsson et al., 2011b). Other volcanic centers may have been eroded or remain hidden beneath ice caps.

(iv) All Bjørndalen bentonite layers contain detrital zircons with four distinct $\mathrm{U}-\mathrm{Pb}$ age groups of Neoarchean (2800-2700 Ma), Paleoproterozoic (1900-1800 Ma), late Grenvillian (1000-900 Ma), and Neoproterozoic/Phanerozoic age $(650-200 \mathrm{Ma})$. The constant zircon age patterns indicate that the clastic sediments hosting the bentonite layers originated from the same source over the whole time of deposition of the Basilika Formation.

(v) The Grenvillian age group is very small, thus excluding a significant input from local sources or from westerly sources and pointing to a predominantly eastern provenance. The most important source seems to have been the Cretaceous Verkhoyansk Fold-and-Thrust Belt exposed in Siberia more than $3000 \mathrm{~km}$ away from Svalbard.

(vi) Several sediment transport mechanism are conceivable, such as ice rafting or alongshore currents following the northern edge of the Eurasian continental margin. Also, multi-stage sediment transport including intermediate storage and later reworking of the Siberian detritus in Mesozoic sediments may explain the zircon age signature of the Basilika Formation. Further provenance studies on different stratigraphic layers and locations across the Arctic are required to gain a better understanding of Paleocene sediment pathways, current systems, fluvial drainage systems, and transport mechanisms.

\section{AUTHOR CONTRIBUTIONS}

FE, CS, SE, FL designed research; FE, SE, DD, LR, FH, NA, RD performed research; FE, CS, SE, DD, LR, FH, RD, KP analyzed 
data; and FE, CS, SE wrote the paper with input from all co-authors.

\section{ACKNOWLEDGMENTS}

We thank Franz Tessensohn and Hans Paech for providing information on CASE 1 bentonite samples. Lotte M. Larsen

\section{REFERENCES}

Akinin, V. V., Prokopiev, A. V., Toro, J., Miller, E. L., Wooden, J., Goryachev, $\mathrm{N}$. A., et al. (2009). U-Pb SHRIMP ages of granitoides from the main batholith belt (North East Asia). Dokl. Earth Sci. 426, 605-610. doi: $10.1134 / \mathrm{S} 1028334 \mathrm{X} 09040217$

Anfinson, O. A., Embry, A. F., and Stockli, D. F. (in press). Geochronologic constraints on the permian-triassic northern source region of the sverdrup basin, Canadian Arctic Islands. Tectonophysics. doi: 10.1016/j.tecto.2016.02.041

Asch, K. (2005). The 1:5 Million International Geological Map of Europe and Adjacent Areas - IGME 5000. Hannover: BGR.

Bergh, S. G., Braathen, A., and Andresen, A. (1997). Interaction of basementinvolved and thin-skinned tectonism in the tertiary fold-thrust belt of central Spitsbergen, Svalbard. Am. Assoc. Pet. Geol. Bull. 81, 637-661.

Blythe, A. E., and Kleinspehn, K. L. (1998). Tectonically versus climatically driven Cenozoic exhumation of the Eurasian plate margin, Svalbard: Fission track analyses. Tectonics 17, 621. doi: 10.1029/98TC01890

Braathen, A., Bergh, S. G., and Maher, H. D. (1999). Application of a critical wedge taper model to the Tertiary transpressional fold-thrust belt on Spitsbergen, Svalbard. Geol. Soc. Am. Bull. 111, 1468-1485.

Brown, P. E., Parsons, I., and Becker, S. M. (1987). Peralkaline volcanicity in the Arctic Basin-the Kap Washington Volcanics, petrology and palaeotectonics. J. Geol. Soc. Lond. 144, 707-715. doi: 10.1144/gsigs.144.5.0707

Bruhn, R., and Steel, R. J. (2003). High-resolution sequence stratigraphy of a clastic foredeep succession (Paleocene, Spitsbergen): an example of peripheralbulge-controlled depositional architecture. J. Sediment. Res. 73, 745-755. doi: 10.1306/012303730745

Buchan, K. L., and Ernst, R. E. (2006). "Giant dyke swarms and the reconstruction of the Canadian Arctic Islands, Greenland, Svalbard and Franz Josef Land," in Dyke Swarms: Time Markers of Crustal Evolution, eds E. Hanski, S. Mertanen, T. Rämö, and J. Vuollo (Balkema: Taylor \& Francis), 27-48.

CASE Team (2001). "The evolution of the west spitsbergen fold-and-thrust belt," in Intra-Continental Fold Belts CASE 1: West Spitsbergen, ed F. Tessensohn (Stuttgart: E. Schweizerbart'sche Verlagsbuchhandlung), 733-773.

Cavalcante, F., Belviso, C., Piccarreta, G., and Fiore, S. (2014). Grain-size control on the rare earth elements distribution in the late diagenesis of Cretaceous shales from the Southern Apennines (Italy). J. Chem. 2014:841747. doi: $10.1155 / 2014 / 841747$

Čepek, P. (2001). "Paleogene calcareous nannofossils from the firkanten and sarsbukta formations on Spitsbergen," in Intra-Continental Fold Belts CASE 1: West Spitsbergen, ed F. Tessensohn (Stuttgart: E. Schweizerbart'sche Verlagsbuchhandlung), 535-547.

Čepek, P., and Krutzsch, W. (2001). "Conflicting interpretations of the Tertiary biostratigraphy of Spitsbergen and new palynological results," in IntraContinental Fold Belts CASE 1: West Spitsbergen, ed F. Tessensohn (Stuttgart: E. Schweizerbart'sche Verlagsbuchhandlung), 551-599.

Charles, A. J., Condon, D. J., Harding, I. C., Pälike, H., Marshall, J. E. A., Cui, Y., et al. (2011). Constraints on the numerical age of the Paleocene-Eocene boundary. Geochem. Geophys. Geosyst. 12, Q0AA17. doi: 10.1029/2010GC003426

Christidis, G. E. (1998). Comparative study of the mobility of major and trace elements during alteration of an andesite and a rhyolite to bentonite, in the Islands of Milos and Kimolos, Aegean, Greece. Clays Clay Miner. 46, 379-399. doi: 10.1346/CCMN.1998.0460403

Corfu, F., Polteau, S., Planke, S., Faleide, J. I., Svensen, H., Zayoncheck, A., et al. (2013). U-Pb geochronology of Cretaceous magmatism on Svalbard and Franz and Fernando Corfu are thanked for providing comments that improved this manuscript.

\section{SUPPLEMENTARY MATERIAL}

The Supplementary Material for this article can be found online at: http://journal.frontiersin.org/article/10.3389/feart. 2016.00073

Josef Land, Barents Sea Large Igneous Province. Geol. Mag. 150, 1127-1135. doi: 10.1017/S0016756813000162

Coward, M. P., Dewey, J., Hempton, M., and Holroyd, J. (2003). "Tectonic evolution," in The Millennium Atlas: Petroleum Geology of the Central and Northern North Sea, eds D. Evans, C. Graham, A. Armour, and P. Bathurst (London: Geological Society), 17-33.

Dallmann, W. K. (1999). Lithostratigraphic Lexicon of Svalbard. Tromsø: Norsk Polarinstitutt.

Dallmann, W. K. (2015). Geoscience Atlas of Svalbard. Tromsø: Norsk Polarinstitutt.

Day, J. M. D., Hilton, D. R., Pearson, D. G., Macpherson, C. G., Kjarsgaard, B. A., and Janney, P. E. (2005). Absence of a high time-integrated ${ }^{3} \mathrm{He} /(\mathrm{U}+\mathrm{Th})$ source in the mantle beneath continents. Geology 33, 733-736. doi: 10.1130/G2 1625.1

Dohrmann, R., Genske, D., Karnland, O., Kaufhold, S., Kiviranta, L., Olsson, S., et al. (2012). Interlaboratory CEC and exchangeable cation study of bentonite buffer materials: I. Cu(II)-triethylenetetramine method. Clays Clay Miner. 60, 162-175. doi: 10.1346/CCMN.2012.0600206

Dörr, N., Clift, P. D., Lisker, F., and Spiegel, C. (2013). Why is Svalbard an island? Evidence for two-stage uplift, magmatic underplating, and mantle thermal anomalies. Tectonics 32, 1-14. doi: 10.1002/tect.20039

Dörr, N., Lisker, F., Clift, P. D., Carter, A., Gee, D. G., Tebenkov, A. M., et al. (2012). Late Mesozoic-Cenozoic exhumation history of northern Svalbard and its regional significance: constraints from apatite fission track analysis. Tectonophysics 514-517, 81-92. doi: 10.1016/j.tecto.2011.10.007

Døssing, A., Hopper, J. R., Olesen, A. V., Rasmussen, T. M., and Halpenny, J. (2013a). New aero-gravity results from the Arctic: linking the latest Cretaceousearly Cenozoic plate kinematics of the North Atlantic and Arctic Ocean. Geochem. Geophys. Geosystems 14, 4044-4065. doi: 10.1002/ggge.20253

Døssing, A., Jackson, H. R., Matzka, J., Einarsson, I., Rasmussen, T. M., Olesen, A. V., et al. (2013b). On the origin of the Amerasia basin and the high arctic large igneous province-Results of new aeromagnetic data. Earth Planet. Sci. Lett. 363, 219-230. doi: 10.1016/j.eps1.2012.12.013

Døssing, A., Japsen, P., Watts, A. B., Nielsen, T., Jokat, W., Thybo, H., et al. (2016). Miocene uplift of the NE Greenland margin linked to plate tectonics: seismic evidence from the Greenland Fracture Zone, NE Atlantic. Tectonics 35, 257-282. doi: 10.1002/2015TC004079

Dypvik, H., and Nagy, J. (1978). Early tertiary bentonites frorn Svalbard; a Preliminary Report. Polarforschung 48, 139-150.

Embry, A. F., and Osadetz, K. G. (1988). Stratigraphy and tectonic significance of Cretaceous volcanism in the Queen Elizabeth Islands, Canadian Arctic Archipelago. Can. J. Earth Sci. 25, 1209-1219. doi: 10.1139/e88-118

Estrada, S. (2015). Geochemical and Sr-Nd isotope variations within Cretaceous continental flood-basalt suites of the Canadian High Arctic, with a focus on the Hassel Formation basalts of northeast Ellesmere Island. Int. J. Earth Sci. 104, 1981-2005. doi: 10.1007/s00531-014-1066-x

Estrada, S., and Henjes-Kunst, F. (2004). Volcanism in the Canadian high arctic related to the opening of the Arctic Ocean. Zeitschrift Dtsch. Geol. Gesellschaft 154, 579-604.

Estrada, S., and Henjes-Kunst, F. (2013). ${ }^{40} \mathrm{Ar}-{ }^{39} \mathrm{Ar}$ and U-Pb dating of Cretaceous continental rift-related magmatism on the northeast Canadian Arctic margin. Zeitschrift Dtsch. Gesellschaft Geowissenschaften 164, 107-130. doi: 10.1127/1860-1804/2013/0005

Estrada, S., Henjes-Kunst, F., Melcher, F., and Tessensohn, F. (2010). Paleocene alkaline volcanism in the Nares Strait region: evidence from volcanic pebbles. Int. J. Earth Sci. 99, 863-890. doi: 10.1007/s00531-009-0432-6 
Estrada, S., Höhndorf, A., and Henjes-Kunst, F. (2001). Cretaceous/Tertiary volcanism in North Greenland: the Kap Washington Group. Polarforschung 69, 17-23. doi: 10013/epic.29823.d001

Faleide, J. I., Vågnes, E., and Gudlaugsson, S. T. (1993). Late Mesozoic-Cenozoic evolution of the southwestern Barents Sea in a regional riftshear tectonic setting. Pet. Geol. Conf. Ser. 4, 933-950.

Frisch, T., and Dawes, P. R. (2014). The rotations opening the Central and Northern Atlantic Ocean: compilation, drift lines, and flow lines. Int. J. Earth Sci. 103, 967-969. doi: 10.1007/s00531-013-0980-7

Gaina, C., Gernigon, L., and Ball, P. (2009). Palaeocene-recent plate boundaries in the NE Atlantic and the formation of the Jan Mayen microcontinent. J. Geol. Soc. Lond. 166, 601-616. doi: 10.1144/0016-76492008-112

Gaina, C., Nikishin, A. M., and Petrov, E. I. (2015). Ultraslow spreading, ridge relocation and compressional events in the East Arctic region: a link to the Eurekan orogeny? Arktos 1, 16. doi: 10.1007/s41063-015-0006-8

Gasser, D. (2014). The Caledonides of Greenland, Svalbard and other arctic areas: status of research and open questions. Geol. Soc. Lond. Spec. Publ. 390, 93-129. doi: $10.1144 /$ SP390.17

Gasser, D., and Andresen, A. (2013). Caledonian terrane amalgamation of Svalbard: detrital zircon provenance of Mesoproterozoic to Carboniferous strata from Oscar II Land, western Spitsbergen. Geol. Mag. 150, 1103-1126. doi: $10.1017 /$ S0016756813000174

Gee, D. G., Bogolepova, O. K., and Lorenz, H. (2006). The timanide, caledonide and uralide orogens in the eurasian high arctic, and relationships to the palaeocontinents Laurentia, Baltica and Siberia. Geol. Soc. Mem. 32, 507-520. doi: 10.1144/GSL.MEM.2006.032.01.31

Gee, D. G., and Hellman, F. (1996). Zircon Pb-evaporation ages from the smutsbreen formation, southern Ny Friesland: new evidence for Caledonian thrusting in Svalbard's Eastern Terrane. Zeitschrift Geol. Wissenschaften 24, 429-439.

González López, J. M., Bauluz, B., Yuste, A., Mayayo, M. J., and FernándezNieto, C. (2005). Mineralogical and trace element composition of clay-sized fractions from Albian siliciclastic rocks (Oliete Basin, NE Spain). Clay Miner. 40, 565-580. doi: 10.1180/0009855054040193

Gradstein, F. M., Ogg, J. G., Schmitz, M. D., and Ogg, G. M. (2012). The Geologic Time Scale, Vol. 2. Oxford: Elsevier.

Greiner, B., and Neugebauer, J. (2013). The rotations opening the Central and Northern Atlantic Ocean: compilation, drift lines, and flow lines. Int. J. Earth Sci. 102, 1357-1376. doi: 10.1007/s00531-012-0860-6

Gripp, K. (1927). Beiträge zur Geologie von Spitzbergen. Abhandlungen Naturwissenschaftlichen Vereins Hambg. 21, 1-38.

Grist, A. M., and Zentilli, M. (2004). Preliminary apatite fission track thermal history modelling of the nares strait region of Eastern Ellesmere Island and Northwestern Greenland. Polarforschung 74, 113-127.

Harland, B. W. (1969). "Contribution of Spitsbergen to understanding of the tectonic evolution of the North Atlantic region," in North Atlantic: Geology and Continental Drift. American Association of Petroleum Geologists Memoir 12, ed M. Kay (Tulsa: American Association of Petroleum Geologists), $817-851$.

Harland, W. B. (1997). Geology of Svalbard. London: Geological Society.

Heister, L. E., O’Day, P. A., Brooks, C. K., Neuhoff, P. S., and Bird, D. K. (2001). Pyroclastic deposits within the East Greenland Tertiary flood basalts. J. Geol. Soc. London. 158, 269-284. doi: 10.1144/jgs.158.2.269

Helland-Hansen, W. (1990). Sedimentation in paleogene foreland Basin, Spitsbergen. Am. Assoc. Pet. Geol. Bull. 74, 260-272. doi: 10.1306/0c9b22bd1710-11d7-8645000102c1865d

Hellman, F. J., Gee, D. G., Johansson, Å., and Witt-Nilsson, P. (1997). Single-zircon $\mathrm{Pb}$ evaporation geochronology constrains basement-cover relationships in the lower Hecla Hoek Complex of northern Ny Friesland, Svalbard. Chem. Geol. 137, 117-134. doi: 10.1016/S0009-2541(96)00152-0

Hellman, F. J., Gee, D. G., and Witt-Nilsson, P. (2001). Late archean basement in the bangenhuken complex of the Nordbreen Nappe, western Ny-Friesland, Svalbard. Polar Res. 20, 49-59. doi: 10.1111/j.1751-8369.2001.tb00038.x

Hopper, J. R., Dahl-Jensen, T., Holbrook, W. S., Larsen, H. C., Lizarralde, D., Korenaga, J., et al. (2003). Structure of the SE Greenland margin from seismic reflection and refraction data: implications for nascent spreading center subsidence and asymmetric crustal accretion during North Atlantic opening. J. Geophys. Res. 108, 2269. doi: 10.1029/2002JB001996
Immonen, N. (2013). Surface microtextures of ice-rafted quartz grains revealing glacial ice in the Cenozoic Arctic. Palaeogeogr. Palaeoclimatol. Palaeoecol. 374, 293-302. doi: 10.1016/j.palaeo.2013.02.003

Jackson, H. R., and Gunnarsson, K. (1990). Reconstructions of the Arctic: mesozoic to present. Tectonophysics 172, 303-322. doi: 10.1016/0040-1951(90)90037-9

Johansson, A., Gee, D. G., Larionov, A. N., Ohta, Y., and Tebenkov, A. M. (2005). Grenvillian and Caledonian evolution of eastern Svalbard - a tale of two orogenies. Terra Nov. 17, 317-325. doi: 10.1111/j.1365-3121.2005.00616.x

Johansson, A., Larionov, A. N., Gee, D. G., Ohta, Y., Tebenkov, A. M., and Sandelin, S. (2004). Grenvillian and Caledonian tectono-magmatic activity in northeasternmost Svalbard. Geol. Soc. Mem. 30, 207-232. doi: 10.1144/GSL.MEM.2004.030.01.17

Jones, M., Burgess, S., Eliassen, G., Svensen, H., Planke, S., Jochmann, M., et al. (2015). Arctic volcanism during the Palaeocene and Eocene: the timing and provenance of volcanic ashes in the Central Tertiary Basin, Svalbard. Geophys. Res. Abstr. 17, EGU2015-11468.

Jowitt, S. M., Williamson, M. C., and Ernst, R. E. (2014). Geochemistry of the 130 to $80 \mathrm{Ma}$ Canadian high arctic large igneous province (HALIP) event and implications for Ni-Cu-PGE prospectivity. Econ. Geol. 109, 281-307. doi: 10.2113/econgeo.109.2.281

Kirkland, C. L., Pease, V., Whitehouse, M. J., and Ineson, J. R. (2009). Provenance record from Mesoproterozoic-Cambrian sediments of Peary Land, North Greenland: implications for the ice-covered Greenland Shield and Laurentian palaeogeography. Precambrian Res. 170, 43-60. doi: 10.1016/j.precamres.2008.11.006

Knox, R. W. O., and Morton, A. C. (1988). "The record of early Tertiary N Atlantic volcanism in sediments of the North Sea Basin," in Early Tertiary Volcanism and the Opening of the NE Atlantic, eds A. C. Morton and L. M. Parson (London: Geological Society), 407-419.

Kontak, D. J., Jensen, S. M., Dostal, J., Archibald, D. A., and Kyser, T. K. (2001). Cretaceous mafic dyke swarm, Peary Land, northernmost Greenland: geochronology and petrology. Can. Mineral. 39, 997-1020. doi: 10.2113/gscanmin.39.4.997

Kristoffersen, Y., and Talwani, M. (1977). Extinct triple junction south of Greenland and the Tertiary motion of Greenland relative to North America. Bull. Geol. Soc. Am. 88, 1037-1049.

Krylov, A. A., Andreeva, I. A., Vogt, C., Backman, J., Krupskaya, V. V., Grikurov, G. E., et al. (2008). A shift in heavy and clay mineral provenance indicates a middle Miocene onset of a perennial sea ice cover in the Arctic Ocean. Paleoceanography 23:PA1S06. doi: 10.1029/2007PA001497

Larsen, L. M., Fitton, J. G., and Pedersen, A. K. (2003a). Paleogene volcanic ash layers in the Danish Basin: compositions and source areas in the North Atlantic Igneous Province. Lithos 71, 47-80. doi: 10.1016/j.lithos.2003. 07.001

Larsen, L. M., and Pedersen, A. K. (2009). Petrology of the paleocene picrites and flood basalts on disko and nuussuaq, West Greenland. J. Petrol. 50, 1667-1711. doi: 10.1093/petrology/egp048

Larsen, L. M., Pedersen, A. K., Sundvoll, B., and Frei, R. (2003b). Alkali picrites formed by melting of old metasomatized lithospheric mantle: manitdlat member, vaigat formation, Palaeocene of West Greenland. J. Petrol. 44, 3-38. doi: 10.1093/petrology/44.1.3

Larsen, L. M., Pedersen, A. K., Tegner, C., Duncan, R. A., Hald, N., and Larsen, J. G. (2016). Age of Tertiary volcanic rocks on the West Greenland continental margin: volcanic evolution and event correlation to other parts of the North Atlantic Igneous Province. Geol. Mag. 153, 487-511. doi: 10.1017/S0016756815000515

Lawver, L. A., Müller, R. D., Srivastava, S. P., and Roest, W. (1990). “The opening of the Arctic Ocean," in Geological History of the Polar Oceans: Arctic versus Antarctic, eds U. Bleil and J. Thiede (Dordrecht: Kluwer), 29-62.

Livšic, J. J. (1967). “Tretičnye otloženija zapadnoj časti archipelaga Špicbergen (Tertiary deposits in the western part of the Archipelago of Svalbard)," in Materialy po stratigrafii Špicbergena, ed V. N. Sokolov (Leningrad: NIIGA), 185-204.

Livšic, J. J. (1974). Paleogene deposits and the platform structure of Svalbard. Nor. Polarinstitutt Skr. 159, 1-50.

Lorenz, H., Gee, D. G., Larionov, A. N., and Majka, J. (2012). The GrenvilleSveconorwegian orogen in the high Arctic. Geol. Mag. 149, 875-891. doi: $10.1017 /$ S0016756811001130 
Ludwig, K. R. (1991). ISOPLOT - a Plotting and Regression Program for RadiogenicIsotope Data. USGS Open-File Report 91-445, US Geological Survey.

Maher, H. D. (2001). Manifestations of the Cretaceous high arctic large igneous Province in Svalbard. J. Geol. 109, 91-104. doi: 10.1086/317960

Major, H., Haremo, P., Dallmann, W. K., Kjærnet, T., and Nøttvedt, A. (2001). Geological Map of Svalbard 1:100,000, Sheet C9G Adventdalen. Tromsø: Norwegian Polar Institute.

Major, H., and Nagy, J. (1964). Geological Map of Svalbard C9G, Adventdalen, 1:100,000, Oslo: Norsk Polarinstitutt.

Major, H., and Nagy, J. (1972). Geology of the Adventdalen Map Area. (Tromsø: Norsk Polarinstitutt), 138.

Manum, S. (1962). Studies in the Tertiary flora of Spitsbergen with Notes on Tertiary Floras of Ellesmere Island, Greenland, and Iceland. (Tromsø: Norsk Polarinstitutt), 125.

Manum, S. B., and Throndsen, T. (1986). Age of Tertiary formations on Spitsbergen. Polar Res. 4, 103-131. doi: 10.1111/j.1751-8369.1986.tb00526.x

Miall, A. D. (1991). "Late Cretaceous and Tertiary basin development and sedimentation, Arctic Islands," in Geology of the Innuitian Orogen and Arctic Platform of Canada and Greenland, ed H. P. Trettin (Ottawa: Geological Survey of Canada), 437-458.

Miller, E. L., Soloviev, A., Kuzmichev, A. G., G., Toro, J., and Tuchkova, M. (2008). Jurassic and Cretaceous foreland basin deposits of the Russian Arctic: Separated by birth of the Makarov Basin? Nor. J. Geol. 88, 201-226.

Miller, E. L., Toro, J., Gehrels, G., Amato, J. M., Prokopiev, A., Tuchkova, M. I., et al. (2006). New insights into Arctic paleogeography and tectonics from U-Pb detrital zircon geochronology. Tectonics 25, TC3013. doi: $10.1029 / 2005$ TC001830

Minakov, A., Mjelde, R., Inge, J., Flueh, E. R., Dannowski, A., and Keers, H. (2012). Mafic intrusions east of Svalbard imaged by active-source seismic tomography. Tectonophysics 518-521, 106-118. doi: 10.1016/j.tecto.2011.11.015

Moran, K., Backman, J., Brinkhuis, H., Clemens, S. C., Cronin, T., Dickens, G. R., et al. (2006). The Cenozoic palaeoenvironment of the Arctic Ocean. Nature 441, 601-605. doi: 10.1038/nature04800

Müller, R. D., and Spielhagen, R. F. (1990). Evolution of the Central Tertiary Basin of Spitsbergen: towards a synthesis of sediment and plate tectonic history. Palaeogeogr. Palaeoclimatol. Palaeoecol. 80, 153-172. doi: 10.1016/00310182(90)90127-S

Nagy, J. (1966). Preliminary report on the geology of Eastern Torell Land, Vestspitsbergen. Nor. Polarinstitut Arb. 1964, 69-72.

Neugebauer, J., and Greiner, B. (2014). Reply to: Frisch and Dawes (DOI 10.1007/s00531-013-0980-7) discussion on The rotations opening the Central and Northern Atlantic Ocean: compilation, drift lines, and flow lines (DOI 10.1007/s00531-012-0860-6). Int. J. Earth Sci. 103, 971-976. doi: 10.1007/s00531-013-0981-6

O’Nions, R. K., and Clarke, D. B. (1972). Comparative trace element geochemistrys of Tertiary basalts from Baffin Bay. Earth Planet. Sci. Lett. 15, 436-446.

O’Regan, M., Moran, K., Backman, J., Jakobson, M., Sangiorgi, F., Brinkhuis, H., et al. (2008). Mid-Cenozoic tectonic and paleoenvironmental setting of the central Arctic Ocean. Paleoceanography 23, PA1S20. doi: 10.1029/2007PA001559

Oakey, G. N., and Chalmers, J. A. (2012). A new model for the Paleogene motion of Greenland relative to North America: plate reconstructions of the Davis Strait and Nares Strait regions between Canada and Greenland. J. Geophys. Res. Solid Earth 117, B10401. doi: 10.1029/2011jb008942

Omma, J. E., Pease, V., and Scott, R. A. (2011). U-Pb SIMS zircon geochronology of Triassic and Jurassic sandstones on northwestern Axel Heiberg Island, northern Sverdrup Basin, Arctic Canada. Geol. Soc. Mem. 35, 559-566. doi: $10.1144 / \mathrm{M} 35.37$

Pearce, J. A. (1996). "A user's guide to basalt discrimination diagrams," in Geological Association of Canada Short Course Notes 12, ed D. A. Wyman (St. John's: Geological Association of Canada), 79-113.

Pettersson, C. H., Pease, V., and Frei, D. (2009). U-Pb zircon provenance of metasedimentary basement of the Northwestern Terrane, Svalbard: implications for the Grenvillian-Sveconorwegian orogeny and development of Rodinia. Precambrian Res. 175, 206-220. doi: 10.1016/j.precamres.2009.09.010

Pettersson, C. H., Pease, V., and Frei, D. (2010). Detrital zircon U-Pb ages of Silurian-Devonian sediments from NW Svalbard: a fragment of Avalonia and Laurentia? J. Geol. Soc. Lond. 167, 1019-1032. doi: 10.1144/0016-76492010-062
Philpotts, J., and Schnetzler, C. (1968). Europium anomalies and the genesis of basalt. Chem. Geol. 3, 5-13. doi: 10.1016/0009-2541(68)90009-0

Piepjohn, K., Thiedig, F., and Manby, G. M. (2001). "Nappe-Stacking on Brøggerhalvøya, NW Spitsbergen," in Intra-Continental Fold Belts. CASE 1: West Spitsbergen, Geologisches Jahrbuch (Polar Issue No. 7), ed F. Tessensohn (Stuttgart: E. Schweizerbart'sche Verlagsbuchhandlung), 55-79.

Piepjohn, K., von Gosen, W., Läufer, A., McClelland, W. C., and Estrada, S. (2013). Ellesmerian and Eurekan fault tectonics at the northern margin of Ellesmere Island (Canadian High Arctic). Zeitschrift Dtsch. Gesellschaft Geowissenschaften 164, 81-105. doi: 10.1127/1860-1804/2013/0007

Pitman, W. C., and Talwani, M. (1972). Sea-Floor Spreading in the North Atlantic. Geol. Soc. Am. Bull. 83, 619. doi: 10.1130/0016-7606(1972) 83[619:SSITNA]2.0.CO;2

Pózer Bue, E., and Andresen, A. (2014). "Constraining depositional models in the Barents Sea region using detrital zircon U-Pb data from Mesozoic sediments in Svalbard," in Sediment Provenance Studies in Hydrocarbon Exploration and Production Special Publications, eds R. A. Scott, H. R. Smyth, A. C. Morton, and N. Richardson (London: Geological Society), 261-279.

Prokopiev, A. V., Toro, J., Miller, E. L., and Gehrels, G. E. (2008). The paleo-Lena River -200 m.y. of transcontinental zircon transport in Siberia. Geology 36, 699. doi: 10.1130/G24924A.1

Reinhardt, L., Estrada, S., Andruleit, H., Dohrmann, R., Piepjohn, K., von Gosen, W., et al. (2013). Altered volcanic ashes in Palaeocene and Eocene sediments of the Eureka Sound Group (Ellesmere Island, Nunavut, Arctic Canada). Zeitschrift Dtsch. Gesellschaft Geowissenschaften 164, 131-147. doi: 10.1127/1860-1804/2013/0004

Roest, W. R., and Srivastava, S. P. (1989). Sea-floor spreading in the Labrador Sea: a new reconstruction. Geology 17, 1000-1003.

Røhr, T. S. (2009). Sedimentary Provenance Analysis of Lower Cretaceous Sedimentary Successions in The Arctic; Constraints From Detrital Zircon Data. Ph.D. thesis, University of Oslo.

Røhr, T. S., Andersen, T., and Dypvik, H. (2008). Provenance of lower Cretaceous sediments in the Wandel Sea Basin, North Greenland. J. Geol. Soc. Lond. 165, 755-767. doi: 10.1144/0016-76492007-102

Rollins, M. B., and Pool, D. L. (1968). Measurement of exchangeable cations in bentonites. Clays Clay Miner. 16, 165-172. doi: 10.1346/CCMN.1968.0160207

Saunders, A. D., Fitton, J. G., Kerr, A. C., Norry, M. J., and Kent, R. W. (1997). "The North Atlantic Igneous Province," in Large Igneous Provinces: Continental, Oceanic, and Planetary Flood Volcanism, eds J. J. Mahoney and M. F. Coffin (Washington, DC: American Geophysical Union), $45-93$.

Schlegel, A., Lisker, F., Dörr, N., Jochmann, M., Schubert, K., and Spiegel, C. (2013). Petrography and geochemistry of siliciclastic rocks from the Central Tertiary Basin of Svalbard - implications for provenance, tectonic setting and climate. Zeitschrift Dtsch. Gesellschaft Geowissenschaften 164, 173-186. doi: 10.1127/1860-1804/2013/0012

Scotese, C. R. (2001). Atlas of Earth History, Vol. 1, Paleogeography. Arlington, TX: PALEOMAP Project.

Seton, M., Müller, R. D., Zahirovic, S., Gaina, C., Torsvik, T., Shephard, G., et al. (2012). Global continental and ocean basin reconstructions since $200 \mathrm{Ma}$. Earth Sci. Rev. 113, 212-270. doi: 10.1016/j.earscirev.2012.03.002

Sircombe, K. N. (2004). AgeDisplay: an EXCEL workbook to evaluate and display univariate geochronological data using binned frequency histograms and probability density distributions. Comput. Geosci. 30, 21-31. doi: 10.1016/j.cageo.2003.09.006

Smelror, M., Petrov, O. V., Larssen, G. B., and Werner, S. (2009). Atlas: Geological History of the Barents Sea. Trondheim: Geological Survey of Norway.

Soloviev, A. V., and Miller, E. L. (2014). The U-Pb age dating of detrital zircons from Upper Jurassic-Lower Cretaceous deposits of Stolbovoy Island (New Siberian Islands). Stratigr. Geol. Correl. 22, 507-517. doi: $10.1134 /$ S0869593814050086

Soloviev, A. V., Zaionchek, A. V., Suprunenko, O. I., Brekke, H., Faleide, J. I., Rozhkova, D. V., et al. (2015). Evolution of the provenances of Triassic rocks in Franz Josef Land: U/Pb LA-ICP-MS dating of the detrital zircon from Well Severnaya. Lithol. Miner. Resour. 50, 102-116. doi: $10.1134 /$ S0024490215020054

Spielhagen, R. F., and Tripati, A. (2009). Evidence from Svalbard for nearfreezing temperatures and climate oscillations in the Arctic during the 
Paleocene and Eocene. Palaeogeogr. Palaeoclimatol. Palaeoecol. 278, 48-56. doi: 10.1016/j.palaeo.2009.04.012

Srivastava, S. P. (1985). Evolution of the Eurasian Basin and its implications to the motion of Greenland along Nares Strait. Tectonophysics 114, 29-53. doi: 10.1016/0040-1951(85)90006-X

Steel, R. J., Dalland, A., Kalgraff, K., and Larsen, V. (1981). “The Central Tertiary basin of Spitsbergen: sedimentary development of a sheared margin basin," in Geology of the North Atlantic Borderland: Canadian Society of Petroleum Geologists, Memoir 7, eds J. W. Kerr and A. J. Ferguson (Calgary: Canadian Society of Petroleum Geologists), 647-664.

Steel, R. J., Gjelberg, J., Helland-Hansen, W., Kleinspehn, K., Nottvedt, A., and Larsen, M. R. (1985). "The Tertiary strike-slip basins and orogenic belt of Spitsbergen," in Strike-Slip Deformation, Basin Formation, and Sedimentation, Vol. 37, eds. K. T. Biddle and N. Christie-Blick (Tulsa: SEPM, Special Publication), 339-359.

Storey, M., Duncan, R. A., and Tegner, C. (2007). Timing and duration of volcanism in the North Atlantic Igneous Province: implications for geodynamics and links to the Iceland hotspot. Chem. Geol. 241, 264-281. doi: 10.1016/j.chemgeo.2007.01.016

Storey, M., Duncan, R. A., Pedersen, A. K., Larsen, L. M., and Larsen, H. C. (1998). ${ }^{40} \mathrm{Ar} /{ }^{39} \mathrm{Ar}$ geochronology of the West Greenland Tertiary volcanic province. Earth Planet. Sci. Lett. 160, 569-586. doi: 10.1016/S0012-821X(98)00112-5

Šucha, V., Kraus, I., Gerthofferová, H., Peteš, J., and Sereková, M. (1993). Smectite to Illite Conversion in Bentonites and Shales of the East Slovak Basin. Clay Miner. 28, 243-253. doi: 10.1180/claymin.1993.028.2.06

Sun, S., and McDonough, W. F. (1989). Chemical and isotopic systematics of oceanic basalts: implications for mantle composition and processes. Geol. Soc. Lond. Spec. Publ. 42, 313-345. doi: 10.1144/GSL.SP.1989.042.01.19

Taboada, T., Martínez Cortizas, A., García, C., and García-Rodeja, E. (2006). Particle-size fractionation of titanium and zirconium during weathering and pedogenesis of granitic rocks in NW Spain. Geoderma 131, 218-236. doi: 10.1016/j.geoderma.2005.03.025

Talwani, M., and Eldholm, O. (1977). Evolution of the Norwegian-Greenland Sea. Bull. Geol. Soc. Am. 88, 969-999.

Tarduno, J. A. (1998). "The high Arctic large igneous province," in Abstract, Third International Conference on Arctic Margins (Celle: Federal Institute of Geosciences and Natural Resources).

Taylor, S. R., and McLennan, S. M. (1985). The Continental Crust: Its Composition and Evolution. Oxford: Blackwell.

Tegner, C., Duncan, R. A., Bernstein, S., Brooks, C. K., Bird, D. K., and Storey, M. (1998). ${ }^{40} \mathrm{Ar}^{-39}$-Ar geochronology of Tertiary mafic intrusions along the East Greenland rifted margin: relation to flood basalts and the Iceland hotspot track. Earth Planet. Sci. Lett. 156, 75-88. doi: 10.1016/S0012-821X(97)00206-9

Tegner, C., Storey, M., Holm, P. M., Thorarinsson, S. B., Zhao, X., Lo, C.H., et al. (2011). Magmatism and eurekan deformation in the high arctic large igneous Province: ${ }^{40} \mathrm{Ar}-{ }^{39} \mathrm{Ar}$ age of Kap Washington Group volcanics, North Greenland. Earth Planet. Sci. Lett. 303, 203-214. doi: 10.1016/j.epsl.2010. 12.047

Tessensohn, F., and Piepjohn, K. (2000). Eocene compressive deformation in Arctic Canada, North Greenland and Svalbard and its plate tectonic causes. Polarforschung 68, 121-124. doi: 10013/epic.29798.d001

Tessensohn, F., Henjes-Kunst, F., and Krumm, S. (2001). "K/Ar Dating Attempts on Rocks from the West Spitsbergen Fold-and-Thrust Belt and the Central Basin," in Intra-Continental Fold Belts CASE 1: West Spitsbergen, ed F. Tessensohn (Stuttgart: E. Schweizerbart'sche Verlagsbuchhandlung), 719-728.
Thompson, B., Jakobsson, M., Nilsson, J., Nycander, J., and Döös, K. (2012). A model study of the first ventilated regime of the Arctic Ocean during the early Miocene. Polar Res. 31, 1-19. doi: 10.3402/polar.v31i0.10859

Thompson, R. N. (1975). Palaeocene ignimbrite from Ubekendt Ejland, west Greenland. Lithos 8, 9-14. doi: 10.1016/0024-4937(75)90026-2

Thompson, R. N. (1982). Magmatism of the British Tertiary Volcanic Province. Scottish J. Geol. 18, 49-107. doi: 10.1144/sjg18010049

Thorarinsson, S. B., Holm, P. M., Duprat, H., and Tegner, C. (2011a). Silicic magmatism associated with Late Cretaceous rifting in the Arctic Basinpetrogenesis of the Kap Kane sequence, the Kap Washington Group volcanics, North Greenland. Lithos 125, 65-85. doi: 10.1016/j.lithos.2011.01.013

Thorarinsson, S. B., Holm, P. M., Tappe, S., Heaman, L. M., and Tegner, C. (2011b). Late Cretaceous-Palaeocene continental rifting in the High Arctic: U$\mathrm{Pb}$ geochronology of the Kap Washington Group volcanic sequence, North Greenland. J. Geol. Soc. London. 168, 1093-1106. doi: 10.1144/0016-764920 11-018

Torsvik, T. H., Carlos, D., Mosar, J., Cocks, L. R. M., and Malme, T. N. (2002), "Global reconstructions and North Atlantic paleogeography 440 Ma to Recent," in BATLAS - Mid Norway Plate Reconstruction Atlas with Global and Atlantic Perspectives, ed E. A. Eide (Trondheim: Geological Survey of Norway), 18-39.

Tripati, A. K., Eagle, R. A., Morton, A., Dowdeswell, J. A., Atkinson, K. L., Bahé, Y., et al. (2008). Evidence for glaciation in the Northern Hemisphere back to $44 \mathrm{Ma}$ from ice-rafted debris in the Greenland Sea. Earth Planet. Sci. Lett. 265, 112-122. doi: 10.1016/j.epsl.2007.09.045

Tsikalas, F., Eldholm, O., and Faleide, J. I. (2002). Early Eocene sea floor spreading and continent-ocean boundary between Jan Mayen and Senja fracture zones in the Norwegian-Greenland Sea. Mar. Geophys. Res. 23, 247-270. doi: 10.1023/A:1023621228605

Uroza, C. A., and Steel, R. J. (2008). A highstand shelf-margin delta system from the Eocene of West Spitsbergen, Norway. Sediment. Geol. 203, 229-245. doi: 10.1016/j.sedgeo.2007.12.003

von Gosen, W., and Piepjohn, K. (2001). "Thrust Tectonics North of Van Keulenfjorden," in Intra-Continental Fold Belts. CASE 1: West Spitsbergen, Geologisches Jahrbuch (Polar Issue No. 7), ed F. Tessensohn (Stuttgart: E. Schweizerbart'sche Verlagsbuchhandlung), 247-272.

Vonderbank, K. (1970). Geologie und Fauna der tertiären Ablagerungen ZentralSpitzbergens. (Tromsø: Norsk Polarinstitutt), 153.

Wilson, M. (1989). Igneous Petrogenesis. London: Chapman \& Hall.

Winchester, J., and Floyd, P. (1977). Geochemical discrimination of different magma series and their differentiation products using immobile elements. Chem. Geol. 20, 325-343. doi: 10.1016/0009-2541(77)90057-2

Worsley, D. (1986). Evolution of an Arctic Archipelago: The Geological History of Svalbard. Stavanger: Den norske stats oljeselskap a.s.

Conflict of Interest Statement: The authors declare that the research was conducted in the absence of any commercial or financial relationships that could be construed as a potential conflict of interest.

Copyright (c) 2016 Elling, Spiegel, Estrada, Davis, Reinhardt, Henjes-Kunst, Allroggen, Dohrmann, Piepjohn and Lisker. This is an open-access article distributed under the terms of the Creative Commons Attribution License (CC BY). The use, distribution or reproduction in other forums is permitted, provided the original author(s) or licensor are credited and that the original publication in this journal is cited, in accordance with accepted academic practice. No use, distribution or reproduction is permitted which does not comply with these terms. 